\title{
船尾大ブロックの移動による新造船 方式について
}

\author{
正員吉且 倰 夫*
}

The New Shipbuilding Method by Shifting Large Stern Block

By Toshio Yoshida, Meinber

Atstract

Kawasaki Dockyard Company, breaking out of the old shell of hull building technique, has adopted a new shipbuilding technique conceived under a new idea. Under this new idea a large stern block previously built is shifted on to an adjacent building berth and there outfitting of the stern parts is continued. In parallel with such work the rest of the hull construction and the outfitting work are kept on while engine installation, electric wirings, and deck outfitting are completed, and then the ship is launched.

The objectives of such procedure are to shorten the time needed for all the outfittings, which are usually carried out on the launched ship moored to a whariside, and also to do away with subsequent docking.

Briefly speaking, the summary of shifting work is as follows :

The 2,800 $\mathrm{T}$ stern block is pulled transversely along eight rows of greased sliding ways and then made to slide down two rows of greased standing ways longitudinally by means of a single wire rope, respectively.

The pulling arrangements including wire and winch etc. are planned on assumption that the frictional coefficient of the grease during the shifting is 0.03 . The speed for pulling and sliding is fixed at $500 \mathrm{~mm} / \mathrm{min}$.

Various measurements are carried out during the shifting. With regard to the stresses caused in the hull during the shifting and readjustment of its position, their maximum values in tension and compression are found to te $2.1 \mathrm{~kg} / \mathrm{mm}^{2}$ and $0.8 \mathrm{~kg} / \mathrm{mm}^{2}$, respectively, which do not differ much when compared with those $\left(1.9 \mathrm{~kg} / \mathrm{mm}^{2}\right.$ in tension, $3.4 \mathrm{~kg} / \mathrm{mm}^{2}$ in compression) measured in hydraulic test of the same stern block. So the figures are by no means serious as hull stress.

Frictional coefficients of the grease, which were experimentally within the range of $0.011 \sim 0.017$ for $20 \mathrm{~T} / \mathrm{M}^{2}$ pressure, were found to be actually 0.029 in maximum, 0.010 in minimum for the lateral shift and 0.022 in maximum, 0.010 in minimum for the longitudinal shift, respectively.

These values of coefficient obtained in actual shifting corresponded, in minimum side, to those of experimental result.

Sand jacks were used in making minute adjustment for the final position of the stern block when it was settled on the berth after a long shifting work.

\section{第 1 章 新造船方式の主旨ならびに工程の概要}

\section{$\$ 1$ 主旨}

近代の造船工作法を概観すれば，これを大きく 3 つの stage に分忛て考觉ることが出来る。第 1 は船殻建造を 主とした進水までの stage であり，第 2 は機関，甲板搫装を主とした進水後の stage であり，第 3 は入渠，運 


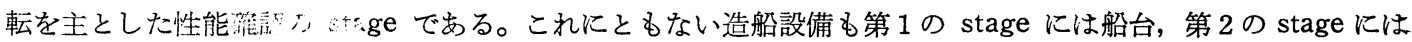
艤装岸壁，第 3 の stage には船渠が不可欠であると考えられてきた。

ここに著者は上記の過去数十年来踏襲されてきた基本的造船工作法の殼を破つてさらに新しい思想に基いた建 造法を試みたのである。それは工程的にも構造的にも船殻, 艤装の両者についてもつとも主要な部分が同一箇所 にあるような船型, たとえば船尾船橋, 船尾機関型油槽船を本方式の対象として考え, まず船台上の船殻工事期 間を短縮するため予め船尾部分を隣接場所で組立て，これを進水可能な船台に移動し，ここで船尾部分の艤装工 事ならびに残りの中央部および船首部の範囲の船殻, 艟装を含む工事を行い（この場合隣接場所ではこれに併行 して次の船の船尾部分の建造を行つている), 船台上で船款工事はもちろん, 機関, 電機, 甲板艤装工事を完成し て進水と同時に，入渠することなく運転を行わんとする方法である。これを簡単に云えば，工作の stage の面に ついては第 1 stage よりただちに第 3 の stage に移るものであり, 設備の面については艤装岸壁, 船渠を不 要とするものである。かように本方式の主旨は船台を中心としてこれに附属する地上組立場 crane 等一連の設備 を用いて生産量を増加し，これらの操業度の向上を計ると同時に船台諸設備および岸壁の利用率を増大せしめ， さらにまた船渠を必要とせぬことによりぼう大な造船設備費の速かな償却あるいは軽減を計り，もつて造船コス. トの低下を実現せんとするにある。

\section{§2 新方式による工程の概要}

第 1 図は以上の考えを線図に示したものである。図中の工程線表は 38,000 T 型油槽船の従来の標準工程を船 台期間で 5 カ月, 進水後引渡しまでを 3 カ月, 計 8 カ月とし, これに対し新造船方式による場合を前者 2 カ月半, 後者 1 カ月半, 計 4 カ月として比較したものである。すなわち新方式によれば船台に隣接せる大組立場で船尾部 分の船体が 2 カ月半で完全に組立てられる。これが本船台に移動後 2 カ月半の期間にて前部船体の建造が行わ

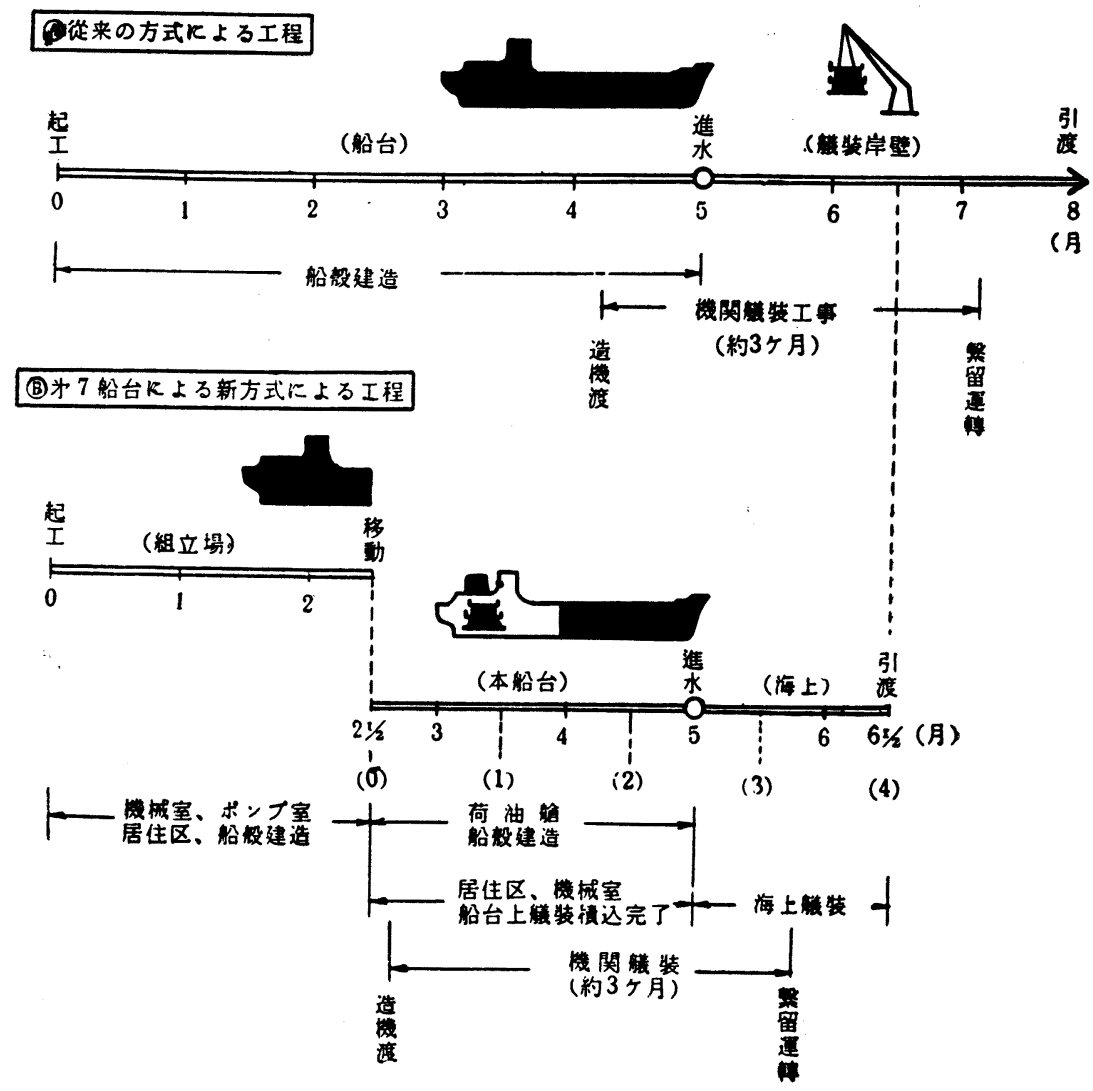

第 1 図 新計画の主旨の線図化 
れ, これと併行して移動された船体および 新しく建造される前部船体に属する艤装工 事が進められるのである。いまこの船款工 事はともかくとして艎装工事についてい允 ば, 移動後数日にして車軸の中心見透しの 後, 船尾部の造機渡しが行われる。

この造機渡しは従来機関艤装の工事開始 を意味すると考えられていたのであるが， 本方式に扣いては同時に甲板蟻装, 電機䇿 装を含むすべての嶬装工事の開始時期と考 えてょい。

いまこの造機渡しょり㢣留運転までの期 間を新旧両方式について比較すると，新方 式によるこの期間は約 3 カ月で従来の期間 に比しなんらの変化なく, 槃留運転から引 渡しまでの期間についても同様である。従 つて䑶装面より見れば，従来の方式が主と して海上で行われ新方式によるものが主と して陸上で行っれる点を除汸ば, 新旧雨者 の間には何の変化もないわけである。

川崎重工業株式会社では昭和 31 年 2 月 第 7 船台を $65,000 \mathrm{~T}$ 型油槽船を建造可能 な船台に拡張すると同時にこの建造法の採 用を決定し，その第 1 船として League Shipping Company S. A. 発註の 38,000T 型油槽船を，組立定船として使用されてい る旧第 3 船台の船尾付近で昭和 31 年 12 月 18 日起工し，ここで総重量 $2,800 \mathrm{~T}$ の船尾 ブロックを建造し昭和 32 年 3 月 12 日これ を隣接の本船台（第 7 船台）へ移動したの である。そして本船はここで船殸工事，艤 装工事を完成し同年 6 月 29 日進水を行つ た。

第 1 表は新方式による $38,000 \mathrm{~T}$ 型油相 船の船殻ならびに艤装各工事の標準主要工 程を示す。

第 2 表は本方式建造による第 1 船の進水 時の実績を基とし，新旧両建造法による場 合のそれぞれの進水時の塔載重量を比較し たものであり，第 3 表は同じく進水時の工 程進捗率を引渡完成時を $100 \%$ として比較 したものである。

これによると船殸工事, 船体, 機関, 電 機の各艤装工事は従来の方法による場合は $92,40,14,19 \%$, 本建造法による場合は $96,86,86,81 \%$ となつており, 総括的に 前者が $60 \%$ であるのにひきか後者では
第 1 裴 新方式による船殼および艤装標準主要工程表（船尾大 ブロック組立期間 2.5 カ月, 第 7 船台期間 2.5 カ月, 進水より引渡までの期間 1.5 カ月)

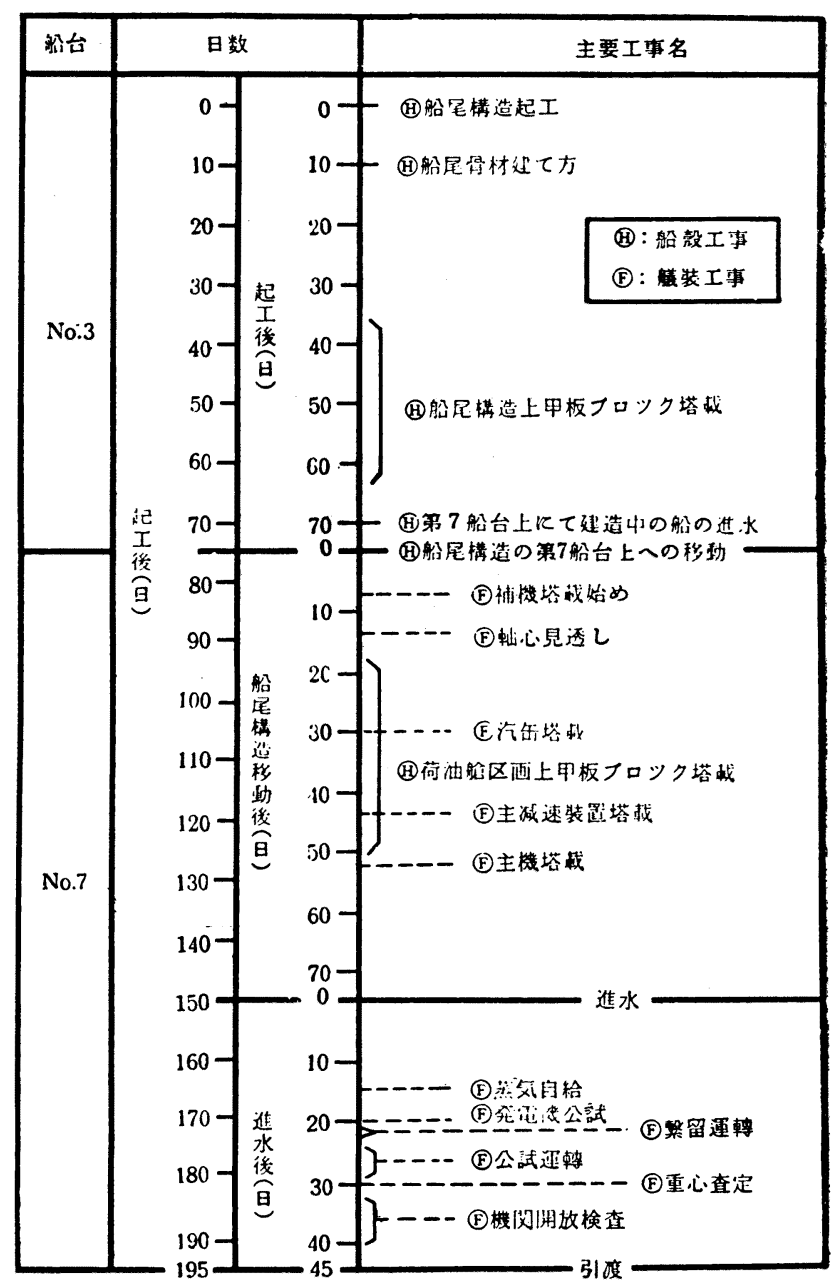

第 2 表 新旧両建造法による進水時の搭載重量の比較

\begin{tabular}{|c|c|c|}
\hline 項 目 ${ }^{\text {建造法 }}$ & 従来の方法による場合 & $\begin{array}{c}\text { 新建造方法による場合 } \\
\text { (第 } 1 \text { 船 実 績) }\end{array}$ \\
\hline 船㪍重量 & $8,578^{T}$ & $8,628^{T}$ \\
\hline 蟻 機装を重含さ量 & $1,067^{T}$ & $2,294^{\mathbf{T}}$ \\
\hline 進水用抱合構造 & $324^{\mathrm{T}}$ & $454^{T}$ \\
\hline 全 重 基 & $9,969 \mathrm{~T}$ & $11,376^{\mathbf{T}}$ \\
\hline 進水合の 巾 & $5^{\prime}-0^{\prime \prime}$ & $\begin{array}{cc}5^{\prime}-\sigma^{\prime \prime} \\
\text { ただし 船尾ブロック } \\
\text { の䉪所のみ } \\
6^{\prime}-6^{\prime \prime}\end{array}$ \\
\hline
\end{tabular}


第 3 表 進水時の工程准捗率

\begin{tabular}{|c|c|c|c|}
\hline & 要工事主 建 造 法 & $\begin{array}{c}\text { 従来の方法 } \\
\text { にる埸 }\end{array}$ & 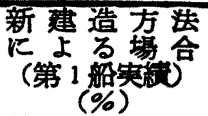 \\
\hline 船 & 款 I 事 & 92 & 96 \\
\hline & 荷 油 艙 内 & 92 & 92 \\
\hline & 上 甲 板 & 71 & 90 \\
\hline & 居 住 区 域 & 20 & 85 \\
\hline & 機関公その他 & 10 & 75 \\
\hline & 計 & 40 & 86 \\
\hline & 主機および軸杀装置 & 10 & 75 \\
\hline 泚过 & 年 & 5 & 90 \\
\hline 関 & 発電機および補機 & 24 & 90 \\
\hline 繶 & 諸管および諸升 & 20 & 95 \\
\hline 㸵 & 雑Ｉ & 5 & 85 \\
\hline & 計 & 14 & 86 \\
\hline 霆 & 電 源 装 置 & 28 & 86 \\
\hline 機 & 照明拉よび通信設備 & 13 & 81 \\
\hline 艤 & 無 線 設 備 & 6 & 71 \\
\hline 衣 & 計 & 19 & 81 \\
\hline & 計 & 60 & 92 \\
\hline
\end{tabular}

$92 \%$ と 5 割以上の增加が見られ，本建造法に よる場合は進水時にほとんど完成に近い状態 にあることがうかがえるのである。ことに機

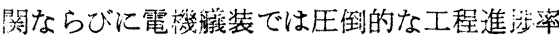
の増加を示している。

第 2 図は参考亡でに附した船尾大ブロック の組立場（旧第 3 船台）ならびに隣接の本船 台（第 7 船台）の配置図である。

\section{第 2 章 移 動 工 事}

\section{\$1 計画基礎諸元の決定}

移動工事の計画を行らに当り最初にその基 礎的事項である移動総重量，使用移動台，摩 擦係数, 戈引方法むよび移動重量重心位置を 次のごとく決定した。

\section{1. 移動総重量の筆定}

移動を行つたブロックは，船尾に上部構造 を有する船尾機関, 船尾船橋型の $38,000 \mathrm{~T}$ 型 油槽船の上部構造を含む No. 11 荷油艙より 船尾の部分である。

この 38,000 T 型油槽船の主要目执よび船 尾ブロックの重量は第 4 表のと和りである。

\section{2. 使用移動台の決定}

組立場（旧第 3 船台）で建造された船尾ブ ロックは船台中心線に直角方向に隣接の第 7 船台まで水平に横移動し，さらに第 7 船台上

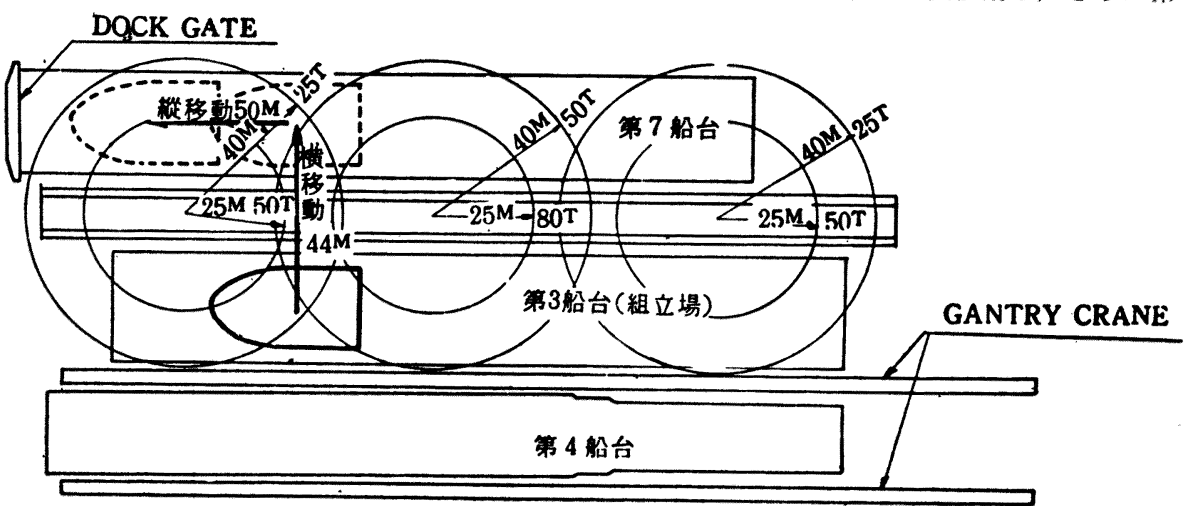

第 2 図第 3,7 船台附近略図

そ所定位置をで船尾方向に移動するものとした。

この移動には川崎重工業株式会社が進水工事の practice としている“獣脂を使用する方法”を採用すること とし，横移動では第 4 船台建造の油槽船に使用する進水台を流用し，縦移動では第 7 船台建造船進水直後その進 水台を利用することとした。

使用せる移動台の要目は第 6 表のと学りである。

\section{3. 麾㩯係数の決定}

移動方法は前述のごとく獣脂を使用する方法を採用したが，第 3 船台より第 7 船台への横移動のごとく，水平 に牽引する場合は進水工事の場侴と異り setting 作業による滑走台の slip が起らぬおそれがあり, 移動開始直 
第 4 表 38,000 型淊䄚船ならでにての船尾ブロック $38,000 \mathrm{~T}$ 羿泣槽船主要目表

\begin{tabular}{|c|c|}
\hline 船殼重量 & $2,610^{\prime}$ \\
\hline 檥 装重量 & $64^{T}$ \\
\hline 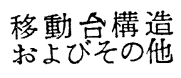 & 約 $126^{\mathrm{T}}$ \\
\hline 総移動重量 & $2,800^{T}$ \\
\hline
\end{tabular}

\begin{tabular}{|c|c|}
\hline 船 級 & A. B. S \\
\hline 垂 線 間長 & $201 \mathrm{M} 000$ \\
\hline 型偪 & $28^{M} 200$ \\
\hline 型深 & $14^{\mathrm{M}} 600$ \\
\hline 満載 吃 水 & $10 M 668$ \\
\hline 総 噸 数 & $24,000 \mathrm{~T}$ \\
\hline 載 荷 重 量 & $.38,600^{\mathrm{T}}$ \\
\hline 船殼鋼材重量 & $8,610^{\mathrm{T}}$ \\
\hline
\end{tabular}

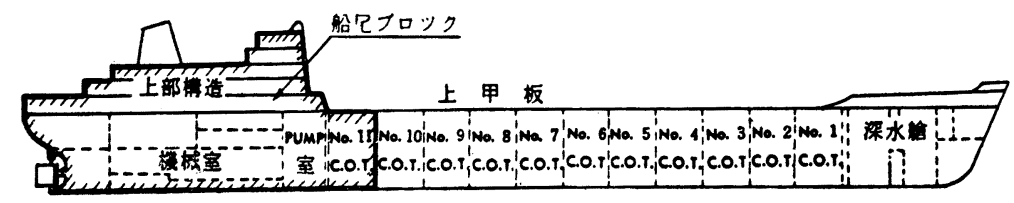

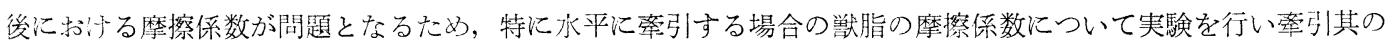
他計画上の摩擦係数を 0.030 とした。

実験に上れば摩擦係数は獣脂沈かる圧力が $20 \sim 30 \mathrm{~T} / \mathrm{M}^{2}$ の範用では移動開始直後上并し $2 \sim 3 \mathrm{~mm}$ 移動後に

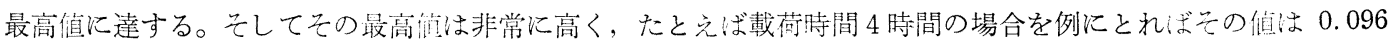
〜0.114であつた。しかしその後は急激汇減 少して載荷時間 4 時間以内ならば $20 \sim 30 \mathrm{~mm}$ 移動すればほぼ定常状態になり，その值は 0.011〜0.023 であつた。

実際の移動工事の結果を解析したところ最 大動摩擦係数は聩移動時約 0.029 , 縦移動時 約 0.022 であり, また平均の摩擦保数涊綐, 第 5 表 使用移動台要目

\begin{tabular}{|c|c|c|}
\hline \multirow{2}{*}{ 横 移 動 台 } & 固定台 (市×厚) & $5^{\prime}-6^{\prime \prime} \times 14^{\prime \prime}$ \\
\hline & 滑走台（巾×厚） & $5^{\prime}-O^{\prime \prime} \times 14^{\prime \prime}$ \\
\hline \multirow{2}{*}{ 縦 移動 台 } & 固定台（巾×厚） & $7^{\prime}-0^{\prime \prime} \times 14^{\prime \prime}$ \\
\hline & 滑走台 (巾×厚) & $5^{\prime}-0^{\prime \prime} \times 14^{\prime \prime}$ \\
\hline
\end{tabular}
僙移動ともに 0.017〜0.020であつた。従つて筫引装置の計画に使用した摩擦係数 0.030 は適当であつたと考兄 られる。

な就移動開始時に率引力を補

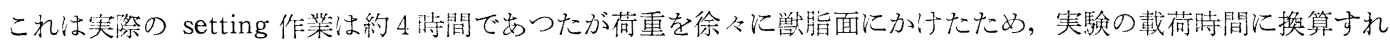
代きわて短時間（滑走台の沈下量より算定すれば 28５0 分位と推定される）となり，前述の最大摩擦係数が 0.03 以下であつたからと思われる。

\section{4. 牽引方法の決定}

第 3 船台より第 7 船台への横移動打よび第 7 船台上の縱移動は期に第 7 船台の船首側に 1 台の winch を設计 てこれにより率引するものとした。

また横移動は率引索 1 本で横移動台に平行に率引するよ5にした。ただしこの場合率引力の着力点と摩擦力の 合力の着力点（抗力中心）の船首尾方向の位置を一致させないと, 横移動の進む汇つれて回転運動々船首尾方向 への移動を伴うことになるが，実際には摩擦力の合力の中心を求めることは困難である。

いま，各横移動台に㧍汁る摩擦㐿数が等しいと仮定すれば，上記の抗力中心と移動重量の重心は一致するから 牵引力の着力点は移動重量の重心と一致させるものとし, 後述のごとく各横移動台はそれぞれの摩擦係数が出来 るかぎり等しくなるように配置をした。

\section{5. 移動重量重心位置の決定}

前述のごとく横移動時に船体の回転および船首尾方向への移動運動を起させ妨ためには“各横移動台における 摩擦係数が等しい”と仮定すれば移動重量の重心位置で旁引する必要がある。従つて移動重量の重心の船首尾方 


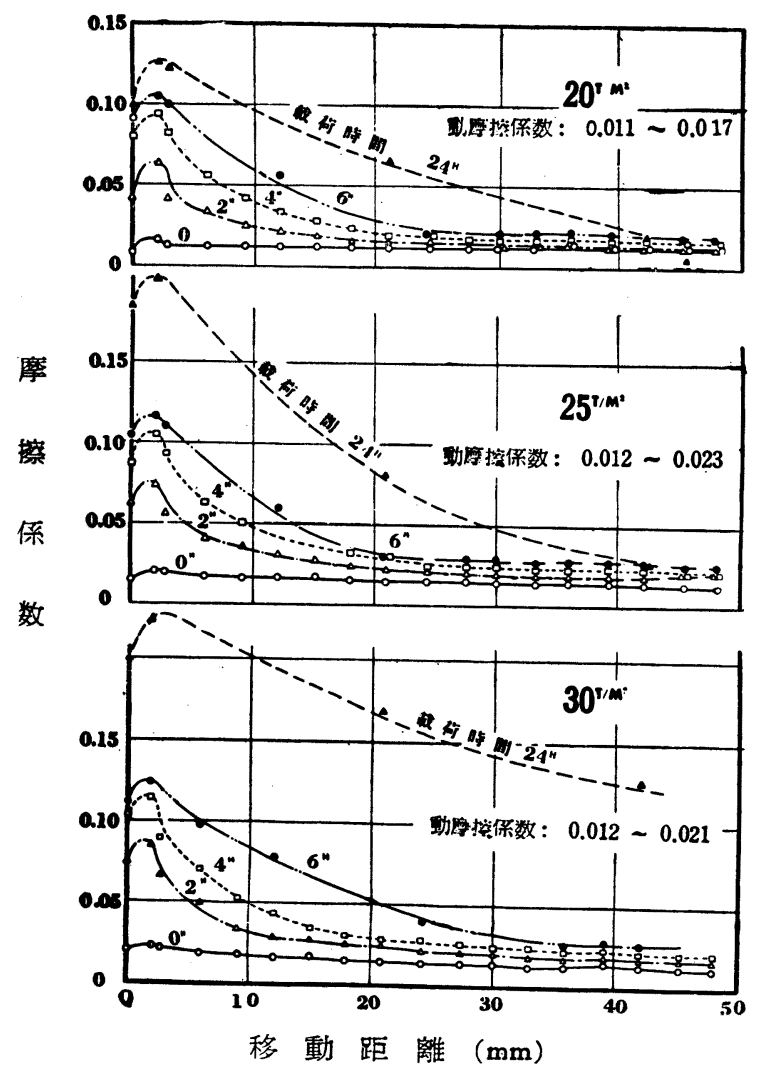

第 3 図 摩擦係数に関する実験結果

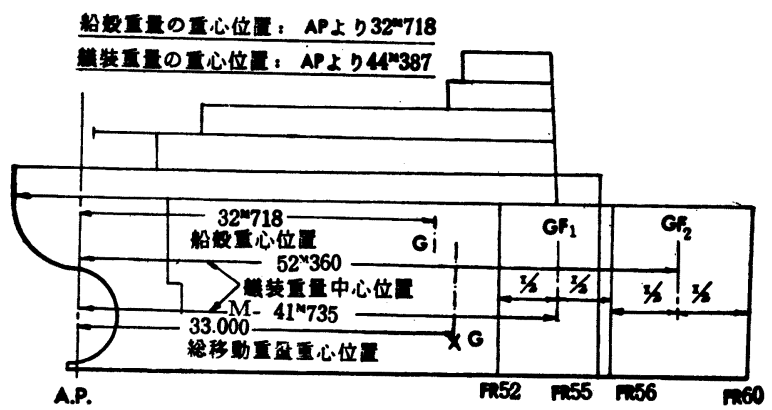

第 4 図移動重量の重心位置

第 6 表 移 動 距 離

\begin{tabular}{|c|c|}
\hline 縱 移 動 距 離 & $50 \mathrm{M}$ \\
\hline 横 移 動 距 離 & $44 \mathrm{M}$ \\
\hline
\end{tabular}

向の位䁂を正確に求める必要がある。

（1）船殻重量の重心位置の算定

船尾ブロックを構成する各部材（plate, stiffener, bracket 等) ごとにその重量と lever を測定して計算した。

その結果船殸重量の重心位置は A.P.より 32 M 718 となつた。

\section{（2）艤装重量の重心位犆}

艤装重量は主ポンプ室, 燃料油艙および No. 11 荷油艙内の pipe, valve だけを算定し，その 他の重量は無視するものとした。そしてこれら の重心位置は第 4 図に示すごとく，主ポンプ室 および然料油艙内のものは，主ポンプ室の中央 $\left(\mathrm{GF}_{1}\right)$ に，また, No.11 荷油艙内のものは, そ の中央 $\left(\mathrm{GF}_{2}\right)$ に重心があるものとして計算し た。

この結果，艤装重量の重心位置は A.P.より 船首側へ $44 \mathrm{M} 387$ となつた。

（3）総移動重量の重心位置

以上の結果により船殻，蟻装合計重量の重心 位置は A.P. より船首側へ 33 M000 となるが， “移動台構造重量およびその他の重量の重心も これと一致する”と仮定すれば，総移動重量の 重心位置は，A.P. より船首側へ $33 \mathrm{M} 000$ とな る。

\section{$\S 2$ 船尾ブロック据付}

第 3 船台にお性る船尾ブロックの据付は次の 条件を考虑して決定するものとした。

a）横移動，縦移動共に移動距離を出来るた け小さくする。

b）横移動は第 7 船台中心線に直角方向に, かつ水平に移動する。

c）縦移動は第 7 船台建造船進水後その進水 台を利用する。

\section{A.P. 位圈の決定}

最船尾側の 横移動固定台 (No. 1 横移動固定 台）の下面が，第 3 拉よび第 7 船台間の tower crane 軌条より僅かに上方にあるようにするた

め，第 3 船台に括ける A.P. は第 7 船台における A.P. 位置より $50 \mathrm{M}$ 船首側とした。

\section{2. 中心線位置の決定}

第 3 および第 7 船台間の tower crane の out-reach を考虑し，該 crane の中心線に関し第 7 船台建造船の 中心線と対称の位置を船尾ブロックの中心線位置とした。

すなわち tower crane 中心線より右舷側に $22 \mathrm{M}$ の距離にある平行線を船尾ブロック中心線とした。

以上の結果移動距離は第 6 表に示すごとく決定された。

\section{3. keel 勾配の決定}




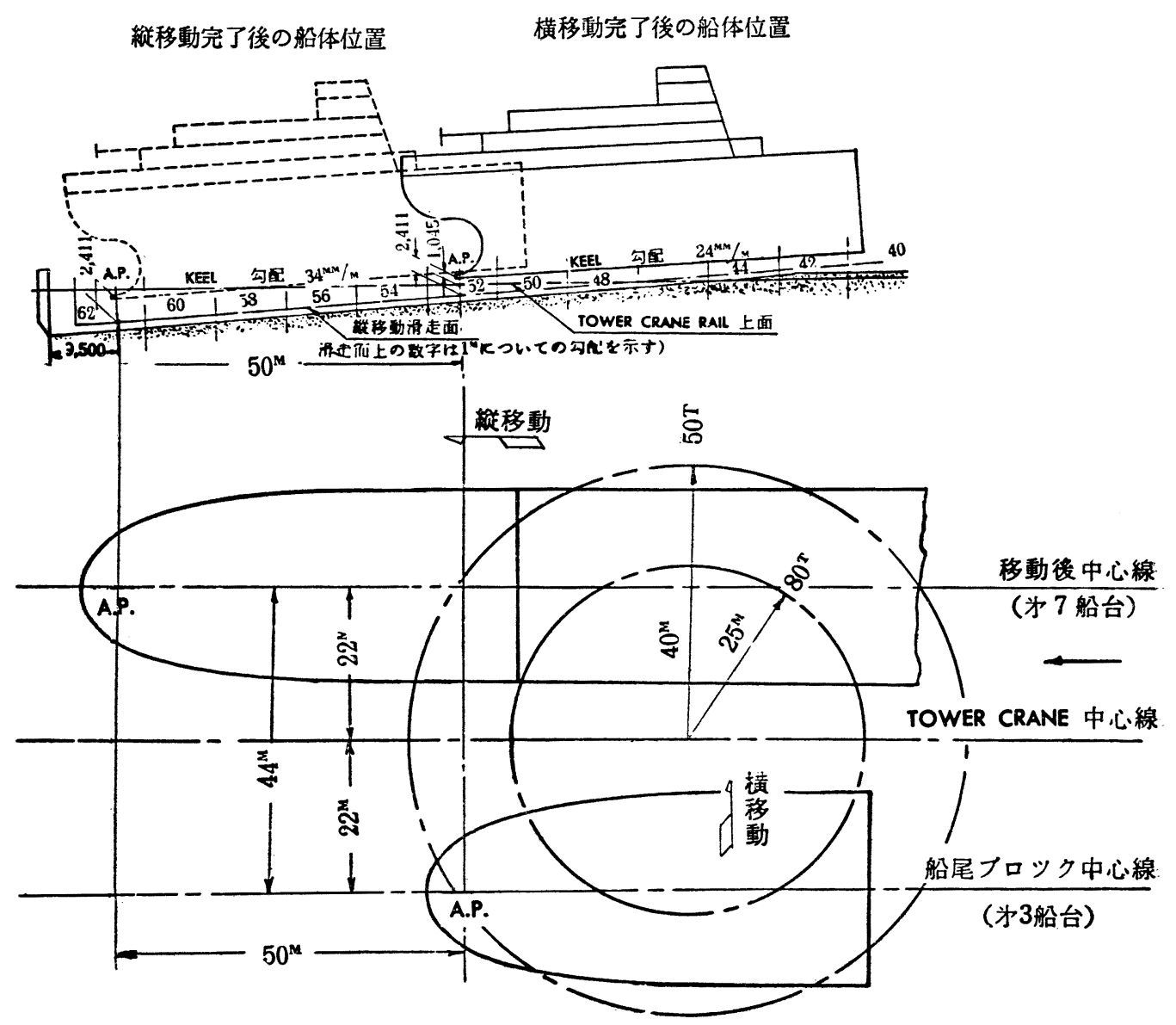

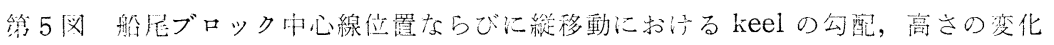

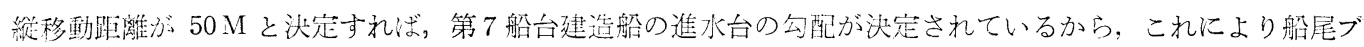
ロッ夕据付の keel 勾配を決定することが出来る。すなわち，この場合船尾ブロックの第3船台に括汀る据付の keel 公配は $1 \mathrm{M}$ につき $24 \mathrm{~mm}$ となる。

4. keel 高さの決定

緃移動距離が決定すれば，第 7 船台建造船の進水台の高さはすでに決定されているから船台におけるブロック 据付の際の keel 高さを決定することが出来る。

すなわち，船尾ブロックの A.P. 位置に㧍子る計算上の高さは tower crane 軌条上面より $1,045.08 \mathrm{~mm}$ とな る。

ただし，実際の建僬に当つては次に述べる船 第 7 表 A. P. における keel の高さ

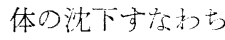

1) 第 3 船守汇扔!ナる船尼ブロック建造中 の船体の沈下

(2) 横移動 setting 作桨による船体の沈下

(3) 横移動洔の船体の沈下

(4) 縱移怔 setting 作栄による船体の沈下

(5) 縱移動㭙の船体の沈下

(6) 綎移動 poppet 取外し作業による船体 の沱下

を考秀て前記の詮算倠よりも $120 \mathrm{~mm}$ 高く据

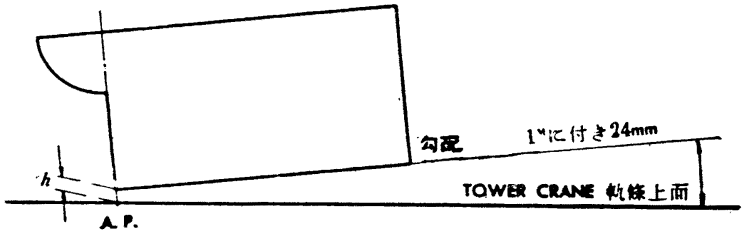

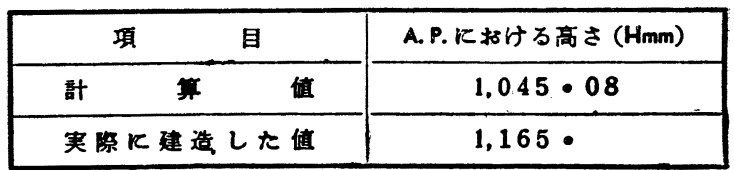


第 8 表 建造拈よび移動による船体沈下量実績

\begin{tabular}{|c|c|}
\hline 第 3 船合における建造中の船体の沈下量 & $9.5 \mathrm{~mm}$ \\
\hline 棤移動 setting 作栄による船体の沈下量 & $11.5 \mathrm{~mm}$ \\
\hline 横 移動 時 の船 体 の沈下量 & $26.0 \mathrm{~mm}$ \\
\hline 縦移動 setting 作觉による船体の沈下星 & $2.0 \mathrm{~mm}$ \\
\hline 絽移哩 時 の 船 体 の 沈下王 & $45.0 \mathrm{~mm}$ \\
\hline $\begin{array}{l}\text { 絽移動 poppet 取外し作業による船体の } \\
\text { 㴶下 }\end{array}$ & $25.0 \mathrm{~mm}$ \\
\hline 合 計 沈 下 & $119.0 \mathrm{~mm}$ \\
\hline
\end{tabular}

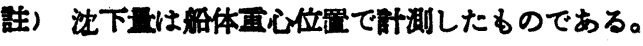

付计て建造を行つた。

実際に横移動を行つた結果によれば建造抒 よび移動による船体重心位置の沈下量の実績 は第 8 表のと打りとなつており推定值と大体 一致した。

\section{$\S 3$ 横移動台配置}

前述のごとく各横移動台に拈ける摩擦係数 が等しく, かつ率引の際移動重量の重心位置 の決定に誤りがなければ船星ブロックは横移 動時, 回転運動および船首尾方向の移動運動 を起さない。このため各横移動台に括ける獣

脂面への圧力を出来るだけ均等にすることが望ましいと考えられる。

そしてこの船尾ブロックは parallel part を含まないため, 滑走台の長さが長くなると，それだけ横移動 poppet の高さが高くなり移動工事に手間と期間がかかる。

従つて次の条件を考虑して横移動台の軌条数を決定するとともにその配置を計画するすのとした。

a）各横移動台の獣脂面への圧力を出来るだけ均等にする。すなわち大型船の進水工事にならい平均任力を約 $20 \mathrm{~T} / \mathrm{M}^{2}$ とする。

b）横移動 poppet の高さを出来るだけ低くする。

\section{1. 横移動台軌条数の決定}

総移動重量 $2,800 \mathrm{~T}$ に対し獣脂面への平均压力 $20 \mathrm{~T} / \mathrm{M}^{2}$ とするためには $140 \mathrm{M}^{2}$ の面積が必要となり, これ を滑走台の巾 $5^{\prime} て ゙$ 除した結果, 横移動滑走台の総長は約 $92 \mathrm{M}$

を必要とすることになる。

いま仮りに横移動台の配置をFR $22, \mathrm{FR} 32, \mathrm{FR} 46, \mathrm{FR} 53^{1 / 2}$ の 4 カ所とし，その位置に淤るる poppet の高さを base line より $1.5 \mathrm{M}$ 以下としてそれぞれの滑走台の長さを求めると第 9 表のごとくその総長は $44 \mathrm{M}$ にしかならない。

従つて獣脂面への平均圧力を約 $20 \mathrm{~T} / \mathrm{M}^{2}$ とするためには横移 動台の必要軌条数は 8 条となる。

2. 横移動滑走台の與さおよび固定台の配置決定

前述のごとく移動台を 8 条とすることとしたが，これらの䇽 第 9 表 滑走台の位置および長さ

\begin{tabular}{|c|c|}
\hline 助 & 滑走合の長さ \\
\hline FR 22 & $4 \mathrm{M}$ \\
\hline FR 32 & $8 \mathrm{M}$ \\
\hline FR 46 & $12 \mathrm{M}$ \\
\hline FR $53 \%$ & $20 \mathrm{M}$ \\
\hline 合 & 到 \\
\hline
\end{tabular}
の扮のに扩獣脂面への 平均圧力が均等となるよう 滑走台の長さ和よび固定台 の位置を定める必要があ る。このため次に述べる仮 定を設けて獣脂面への圧力 を求める計算式を誘導し た。

（1）船体は剛体であ る。

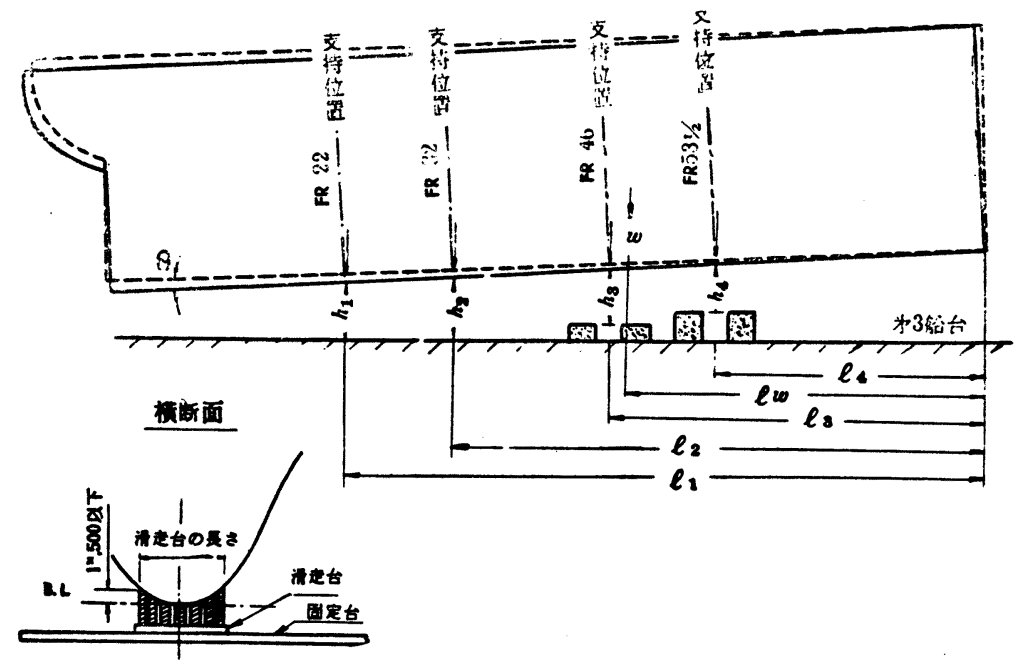

(3) 各支持点において

第 6 因横移動台の配置 
は一種の “ばね”で支持しているものとし，こ れらの “ばね”の剛性率（支持台の見かけの剛 性率) 注一定である。

第 6 図において

$W:$ 総移動重量

$l_{w}:$ FR60より移動重量重心までの縦方向 距離

$l_{n}$ : FR60より各支持点までの縦方向距離

$h_{n}$ : 各支持点における船台 (第 3 船台) と keel 下面との距離（船体の高さ）

$\delta_{n}$ : 各支持点における横移動直前の船体 沈下量

$R_{n}:$ 各支持点に生ずる反力

$\theta$ : 支持台見かけの剛性率

$A_{n}$ : 支持台の受圧面積

とすれば

$$
\begin{gathered}
\delta_{n}=\delta_{1}-a\left(l_{1}-l_{n}\right) \\
\text { ただし } \left.\begin{array}{r}
\tan \theta=a
\end{array}\right\} \\
k_{n} \equiv \frac{h_{n}}{E A_{n}} \text { とすれば } \\
\delta_{n}=k_{n} \cdot R_{n_{b}} \\
W=\sum_{1}^{4} R_{n} \\
W \cdot l_{w}=\sum_{1}^{4} R_{n} \cdot l_{n}
\end{gathered}
$$

\begin{tabular}{|c|c|c|c|}
\hline 解体沈下 & ひたける & Qにたける & t下 $\mathbf{E}(\mathrm{mm})$ \\
\hline 粉 & KEEL の沈下 $\mathbf{E}(\mathrm{mm})$ & 左 藉 & 右 舴 \\
\hline CHRYSANTHY-L 号 & 14 & 14 & 14 \\
\hline MASTER MKCHAEL 号 & 15 & 17 & 16 \\
\hline URGO 号 & 14 & 15 & 16 \\
\hline CHARIOT 号 & 14. 5 & 15 & 1 4. 5 \\
\hline
\end{tabular}

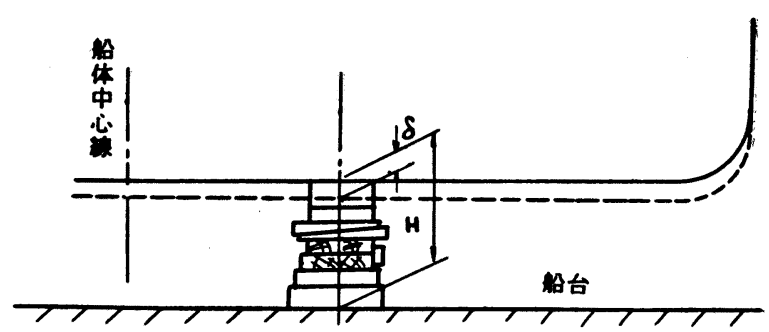

第 7 図進水台断面

第 10 表 $38,000 \mathrm{~T}$ 型油槽船の進水 setting 作業時の船 体沈下量

以上の式より $\delta, R, a$ を求めると (1)(2)り

$$
R_{n}=\left[\delta_{1}-a\left(l_{1}-l_{n}\right)\right] / k_{n 2}
$$

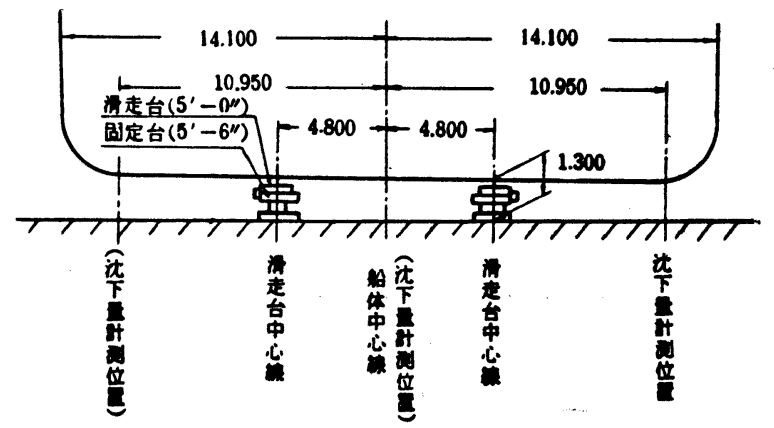

(5)(3)(4)上り

(6) (7)上り

$$
\begin{aligned}
& W=\delta_{1} \sum_{1}^{4} \frac{1}{k_{n}}-a\left[l_{1} \sum_{2}^{4} \frac{1}{k_{n}}-\sum_{2}^{4} \frac{l_{n}}{k_{n}}\right] \\
& W \cdot l_{w}=\delta_{1} \frac{4}{1} \frac{l_{n}}{k_{n}}-a \sum_{2}^{4} \frac{l_{n}\left(l_{1}-l_{n}\right)}{k_{n}}
\end{aligned}
$$

$$
\begin{aligned}
\delta_{1}=W\left\{\sum_{2}^{4} \frac{l_{n}\left(l_{1}-l_{n}\right)}{k_{n}}-l_{w}\left[l_{1} \sum_{2}^{4} \frac{1}{k_{n}}-\sum_{2}^{4} \frac{l_{n}}{k_{n}}\right]\right\} \times\left\{\sum_{1}^{4} \frac{1}{k_{n}} \cdot \sum_{2}^{4} \frac{l_{n}\left(l_{1}-l_{n}\right)}{k_{n}}\right. \\
\left.\quad-\sum_{1}^{4} \frac{l_{n}}{k_{n}}\left[l_{1} \sum_{2}^{4} \frac{1}{k_{n}}-\sum_{2}^{4} \frac{l_{n}}{k_{n}}\right]\right\}^{-1} \\
a=W\left[\sum_{1}^{4} \frac{l_{n}}{k_{n}}-l_{w} \sum_{1}^{4} \frac{1}{k_{n}}\right] \times\left\{\sum_{1}^{4} \frac{1}{k_{n}} \sum_{2}^{4} \frac{l_{n}\left(l_{1}-l_{n}\right)}{k_{n}}-\sum_{1}^{4} \frac{l_{n}}{k_{n}}\left[l_{1} \sum_{\nu}^{4} \frac{1}{k_{w}}-\sum_{\nu}^{4} \frac{l_{n}}{k_{n}}\right]\right\}^{-1}
\end{aligned}
$$

故に横移動台（支持台）の見かけの剛性率 (E) が判明すれば滑走台の長さおよび固定台の配置に応じて(5)（8， (9より反力 $R_{n}$ を求めることができ，従つて各横移動台における獣脂面への圧力 $R_{n} / A_{n}$ (反力/断面積）を求め ることが出来る。

横移動台（支持台）の見かけの剛性率 $(E)$ は川崎重工業株式会社に批第 4 船台建造 38,000 T 型油槽船の。 進水台の見かけの剛性率を次の方法で求めてこれを使用することとした。

いま

進水台の見かけの剛性率 $-E^{\prime}$

進水重量 $W$ 
滑走台面積—A

進水台位置の船体の高さ(進水台の盤木高さ;一一 - $H$

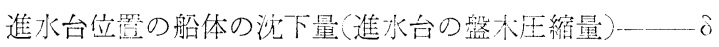

とすれ菻 $E^{\prime}$ は次の式であら京される。

$$
E^{\prime}=\frac{W / A}{\delta / H}
$$

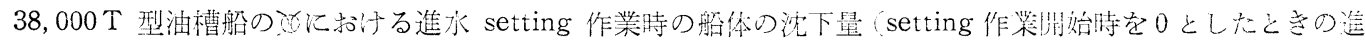
水直前の船体の沈下量) の計測結果を第 10 表汇示す。

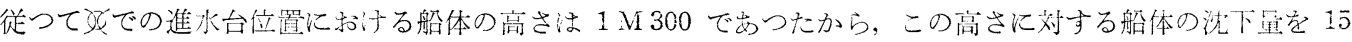
$\mathrm{mm}$ と考えることとした。

また $38,000 \mathrm{~T}$ 型油槽船の進水重量は 9, $947 \mathrm{~T} 620$ で，滑走台の面積は $521.540 \mathrm{M}^{2}$ であつた。

従つてこれらの数值を前述の式に代入すると, 進水台の見かけの剛性率 $\left(E^{\prime}\right)=1,650 \mathrm{~T} / \mathrm{M}^{2}$ そしてこの場合の 獣脂面への圧力 $W / A\left(\frac{\text { 進水重量 }}{\text { 滑走台面積 }}\right)$ は $19.07 \mathrm{~T} / \mathrm{M}^{2}$ である。移動計画における獣脂面への計画圧少は $20 \mathrm{~T} / \mathrm{M}^{2}$ であり,船体の高さも後述のごとく $1 \mathrm{M} 500$ 附近で進水台の場合とはなはだしい相異はないた方進皮台の見かけ の剛性率と横移動台の見かけの剛性率は等しいものと考光ることとした。

すなわち

$$
\text { 横移動台の見かけの㴊性率 }=1,650 \mathrm{~T} / \mathrm{M}^{2}
$$

上述のごとく横移動台の見かけの剛性率 $(E)$ を $1,650 \mathrm{~T} / \mathrm{M}^{2}$ と算定したから，滑走台の長さ括よび固定台の

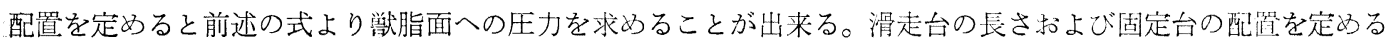
飞当り，横移動の見かけの剛性率を出来るだけ等しくするため，各横移動台位置に打汁る船体の岕さ $\left(h_{n}\right)$ をほ ぼ等しくするよう飞横移動台下部の concrete 盤木を配置するとともに 8 条の横移動台の5ち各 2 条ずつその滑 走面の高さ拉よび滑走台の長さ等の支持条件を等しくし，これら 2 条の中央に計算上の支持点があるものと考光 ることとした。

\begin{tabular}{|c|c|c|c|c|c|c|c|c|}
\hline 計算上の支持 位 置 & \multicolumn{2}{|c|}{ FR22 } & \multicolumn{2}{|c|}{ FR32 } & \multicolumn{2}{|c|}{ FR46 } & \multicolumn{2}{|c|}{ FR53x/2 } \\
\hline 横 移 動 台 番 号 & (1) & (2) & (3) & (4) & (5) & (6) & (7) & (8) \\
\hline 滑 走 台の長さ L & $4^{M}$ & $4^{M}$ & $8^{M}$ & $8^{\mathbf{M}}$ & $12^{\mathrm{M}}$ & $12^{\mathrm{M}}$ & $20^{M}$ & $20^{M}$ \\
\hline 滑 走 台 $の$ 巾 $B$ & \multicolumn{8}{|c|}{$1^{\mathbf{M}_{524}}$} \\
\hline 滑 走 台の面積 A & $\begin{array}{l}\mathbf{M 2} \\
6.1\end{array}$ & $\begin{array}{l}\text { M2 } \\
6.1\end{array}$ & $\begin{array}{c}\mathrm{M} 2 \\
12.3 \\
\end{array}$ & $\begin{array}{c}\mathrm{M}^{2} \\
12.3 \\
\end{array}$ & $\begin{array}{c}\text { M2 } \\
18.3 \\
\end{array}$ & $\begin{array}{c}\text { M2 } \\
18.3 \\
\end{array}$ & $\begin{array}{c}\text { M2 } \\
30.6 \\
\end{array}$ & $\begin{array}{c}\text { M2 } \\
30.6 \\
\end{array}$ \\
\hline 計算上の支持合の受付面積 An & \multicolumn{2}{|c|}{$12.2^{\mathbf{M} 2}$} & \multicolumn{2}{|c|}{$24.6^{\mathrm{M} 2}$} & \multicolumn{2}{|c|}{$36.6^{\mathrm{M} 2}$} & \multicolumn{2}{|c|}{$61.2^{\mathrm{M} 2}$} \\
\hline B.Lよりの poppet の高さ & $1^{\mathbf{M}_{14}}$ & $0^{\mathbf{M}_{300}}$ & $1^{M_{15}}$ & $\mathrm{O}_{450}$ & & $\mathrm{O}^{\mathbf{M}_{2}}$ & $1^{\mathbf{M}} 300$ & $0^{\mathrm{M}} 800$ \\
\hline
\end{tabular}

第 11 表 滑 走 台 諸 元

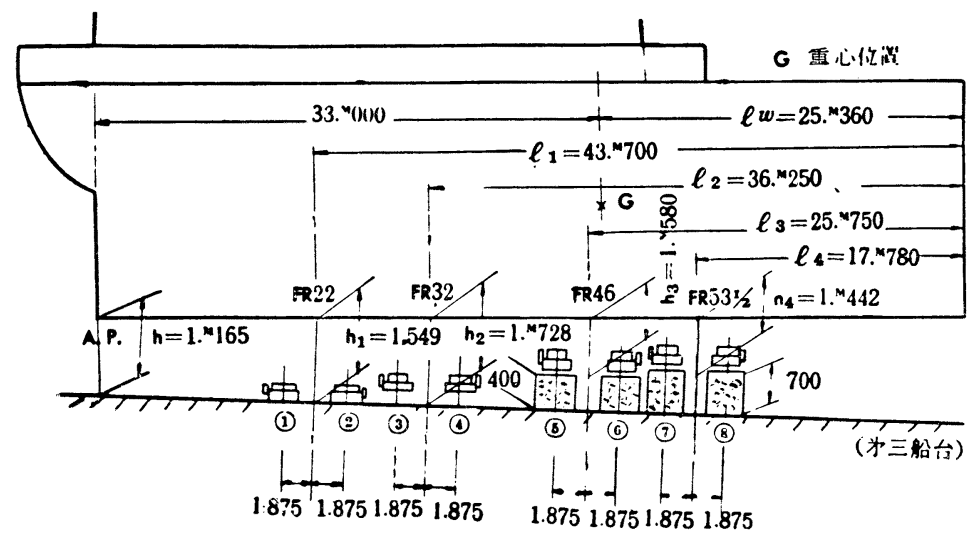




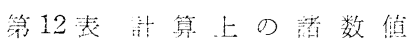

\begin{tabular}{|c|c|c|c|c|c|}
\hline 項 & & 数 & & & 直 \\
\hline 計算上の支持位置 & & FR22 & FR32 & FR46 & FR531/2 \\
\hline FR60 より各支持点までの縦方向距離 & $\ell_{n}$ & $43^{\mathrm{M}} 700$ & $36^{\mathrm{M}} 250$ & $25^{\mathrm{M}} 750$ & $17^{\mathrm{M}} 780$ \\
\hline 計算上の支持位置における船体の高さ & $h_{n}$ & $1^{\mathrm{M}} 549$ & $1^{\mathrm{M}} 728$ & $1^{\mathrm{M}} 580$ & $1^{\mathrm{M}} 442$ \\
\hline 計算上の支持台の受王面積 & $\mathrm{A}_{n}$ & $12.2^{\mathrm{M} 2}$ & $24,6^{\mathrm{M} 2}$ & $36.6^{\mathrm{M} 2}$ & $61 \cdot 2^{\mathrm{M} 2}$ \\
\hline 総移動重量 & $\mathbf{W}$ & \multicolumn{4}{|c|}{$2,800^{T}$} \\
\hline FR60より移動重量の重心までの縦方向距離 & $\ell_{w}$ & \multicolumn{4}{|c|}{$25^{\mathrm{M}} 360$} \\
\hline 横移動台の見かけの剛性率 & $\mathrm{E}$ & \multicolumn{4}{|c|}{$1,650^{\mathrm{T}} / \mathrm{M}^{2}$} \\
\hline
\end{tabular}

第 13 表 横移動台獣脂面への圧力

\begin{tabular}{|c|c|c|c|c|c|}
\hline 計算上の支持位置 & & FR22 & FR32 & FR46 & FR531/2 \\
\hline 横移動台番号 & & (1) (2) & (3) (4) & (5) (6) & (7) (8) \\
\hline 各支持点における横移動洹前のれ下量 & $\delta_{n}$ & $199^{\mathrm{mm}}$ & $197^{\mathrm{mm}}$ & $193^{\mathrm{mm}}$ & $190^{\mathrm{mm}}$ \\
\hline 各支持点に生ずる反力 & $\mathrm{R}_{n}$ & $259^{T}$ & $463^{\mathrm{T}}$ & $748^{\mathrm{T}}$ & $1330^{r}$ \\
\hline 各横移動台に拈ける獣脂画への圧力 & $\mathrm{R}_{n} / \mathrm{A}_{n}$ & $21 \cdot 2^{\mathrm{T}} / \mathrm{M}^{2}$ & $1895 / \mathrm{M}^{2}$ & $204^{T} / M^{2}$ & $23.4 \mathrm{~T} / \mathrm{M}^{2}$ \\
\hline 横移動台の獣脂面への平均圧力 & & \multicolumn{4}{|c|}{$210 \mathrm{~T} / \mathrm{M}=$} \\
\hline
\end{tabular}

いま船体の構造を考虑して次に示すごとくFR $22, F R 32, F R ~ 46, F R ~ 53^{1} / 2$ が計算上の支持位置となるよ $5 に$ 二れらの両側，等距離の位置に横移動台を配置し，またpoppet の高さを考虑して滑走台の長さを定めてみた。

前述の式に第 12 表の数值を代入すると計算上の支持位置（FR 22, FR 32, FR 46 およよ゙ FR 531/2) に沶ける船 体沈下量, 反力, 獣脂面への圧力は第 13 表に示すと㧍りとなる。

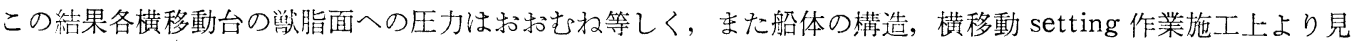
て満足すべき配置と思われるのでこの横移動台配置を採用した。

実際に横移動工事を行つた結果，抗力中心と牽引点との相異は移動中の計画の解析によれば $200 \mathrm{~mm}$ 程度 であり，また獣脂面もNo. 3，No. 4 およびNo. 5, No.6 の横移動台を除いては変化がなかつた。そしてNo. 3, No. 4 および No. 5, No. 6 横移動台の獣脂が横移動時幦開を起したが，これは第 8 図に示す横移動固定台の撓み 測定結果から判明するごとく，各横移動台の圧力が均等でなかつたためでなく，No. 3, No. 4 拈よび No. 5, No.6 の横移動台の poppet の配置が適当でなかつたため，それぞれの滑走台の長さ方向の圧力が不均一でめつ たことに起因するものと考えられる。

従つて横移動台の配置は所期の目的を達成することが出来たものと考えられる。

なお第 8 図の横移動固定台の撓みは図中に示すごとく，25M 移動した位置に固定台の下に dial gauge を置 き，横移動中に移動台が $1 \mathrm{~mm}$ 撓さごとに記録したものである。

\section{$\S 4$ 縋移動台配置}

䇍移動台は前述のごとく第 7 船台建造船の進水後その固定台を流用するため固定台, 滑走台の巾, 滑走台の中 し線間隔およざ国定台の勾院は第 14 表に示すごとく第 7 船台建造船の場合と同一となる。

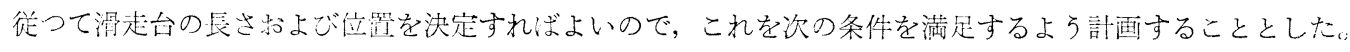

a 獣脂面にかかる压力が各部均等になること。

b 上記平均压力が約 $20 \mathrm{~T} / \mathrm{M}^{2}$ なること。

滑走台は船尾ブロックの重心位置（横移動完了点での）に関し出来るかぎり等距離に配置することを原則とし， さらに船体の固め方 (局部強度) を考えて第14表の図中に示すごとく配置した。 


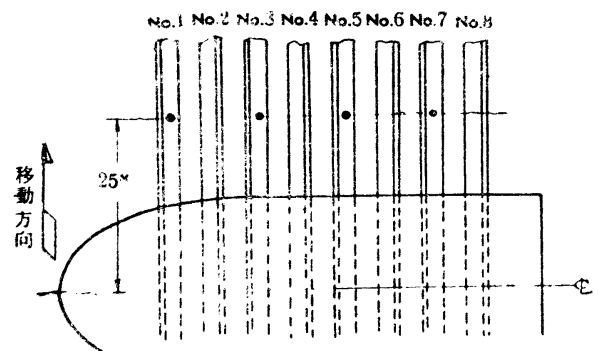

(社)・时は計到位话を小导

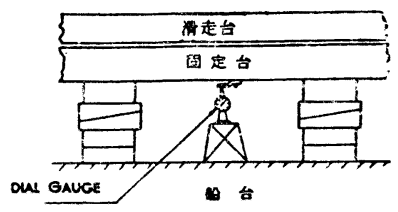

移動方向

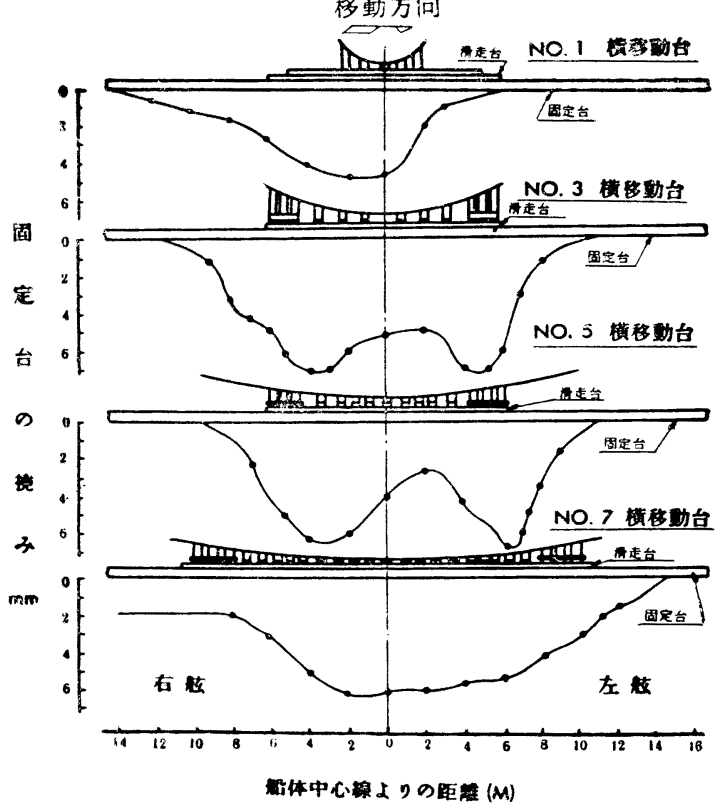

第 8 図横移動固定台撓み測定結果
$\S 5$ 橫移動装置

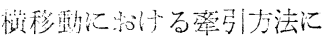
は winch に上る慗淤式を 採用したが，この場会の主蔡 引菜は下就の理由により 1 本 とし 5 枚滑車により增力する こととした。(winch は䌙移 動用を乘用。)

a) 率引索を 2 本にした場 合は 2 本の wire の缷取速度 を全く同一にすることは負荷 の unbalance 等により難し いと考えられる。

b) 縱移動 winch の他に 㰛移動省用として 2 台の winchが必要となり設備費が 多くなる。

なお牽引索 1 本の場合は前 述のごとくブロックが横振れ するおそれがあるため，この 防止策として船首尾に 2 条の 制動索を張り水压耭にて clampする方法を採用するこ ととした。喷移動装犆に用い た索具類は摩擦係数を 0.03 とした場合の所要率引力に対 乙約 9 乃至 10 の安全率があ るよら計瞫することとし，横

移動開始時の高い摩擦係数に対しては押出装置を設け牵引装每を援助するものとした。

なお上記の安全率は $65,000 \mathrm{~T}$ 型油槽船建造の場合を考虑したため，普通の場合より高く計画することになつ たものである。移動工事に使用する牽引装置の 概要执よび索具決定につき述べる。

1. 所要引力

$R$ : 所要率引力

$W$ : 総移動重量

$\theta$ : 移動台の傾斜角度

$\mu$ ：獣脂の摩擦係数 とすれば,

$R=W \cos \theta(\tan \theta-\mu)$

$W=2,800 \mathrm{~T}, \theta=0, \mu=0.03$ であるから 横移動時の所要引力 $=84 \mathrm{~T}$

2. 滑車

所要黄移動牽引才は 84 T であるが，種々の 抵抗の增加孛考虛して $180 \mathrm{~T}$ (test load : $280 \mathrm{~T}$ の 5 枚滑車とした。

3. 星引索

5 枚滑車を第 9 図に示すように使用した場合

第 14 喪 綎移動用国定台ならびに滑走台

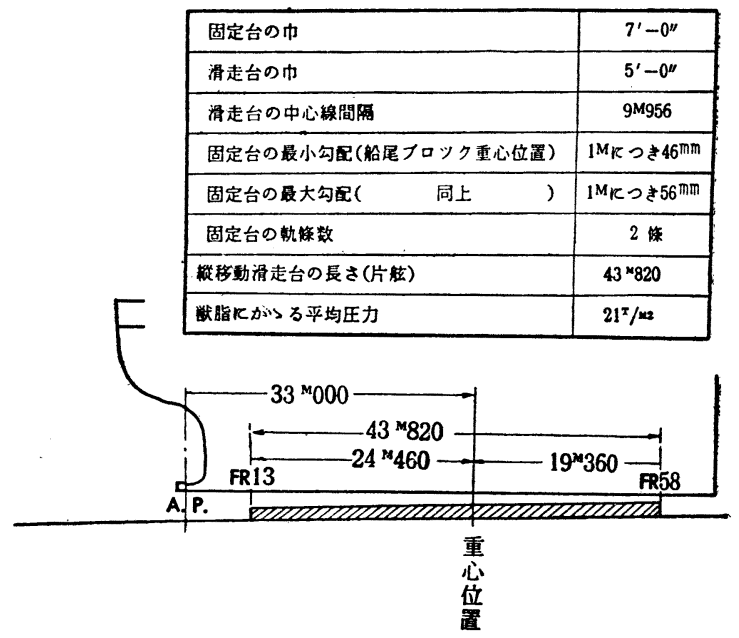


率引索の最大張力を滑車の公式を使用して求 的ると

$$
T_{1}=\frac{X^{n}(X-1)}{X^{n}-1} R
$$

ただし $T_{1}$ : 率引索の最大張力

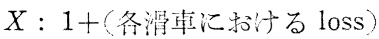

$n:$ 滑些の数

$R:$ 横移動所要率引力

いま $R=84 \mathrm{~T}, n=10$ であり， $x=1.06$ と すれば $T_{1}=11.4 \mathrm{~T}$

率引索觉 $42 \mathrm{~mm} \phi(29$ 本線 6 撚 filler 入り $)$ としたので, 破䉼荷畐 $=110 \mathrm{~T}$

従つて 安全率=9.65 となる。

\section{4. 台 付 索}

船体の重心を通り船体中心線汇直角な直線 に対し $10^{\circ}$ の倾斜で 2 本の台付索を船体に溶 接した 4 ケの台付に連絬した。したがつて台 付索 1 本にかかる荷重梳,

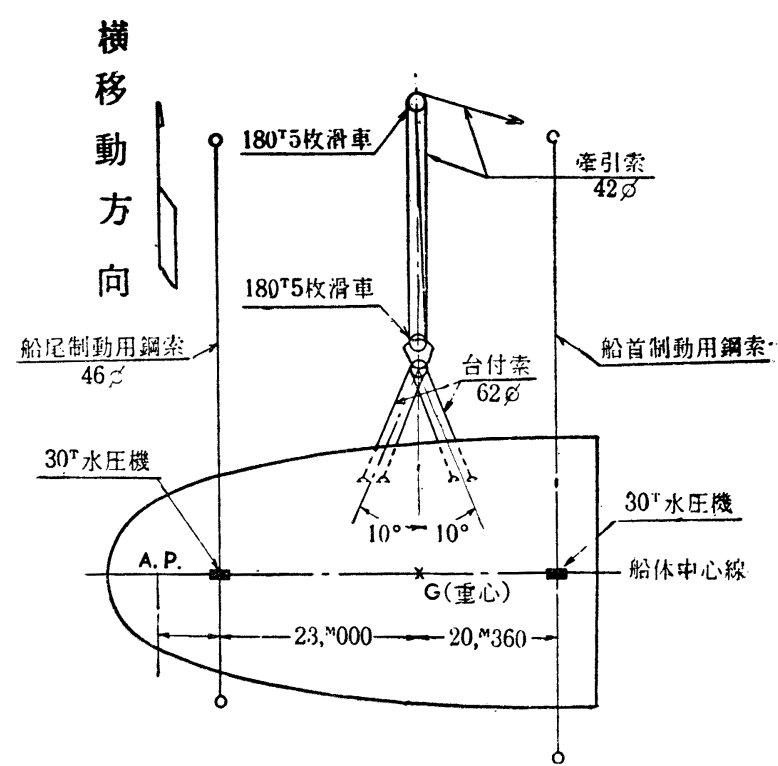

第 9 図 横移動茲引装置配置要领

$$
T_{2}=\frac{R}{4 \cos \theta}
$$

ただし $T_{2}=$ 台付索1本にかかる荷重

$$
\theta=\text { 台付索の角度 }
$$$$
R=\text { 横移動所要索引力 }
$$

いま $R=84 \mathrm{~T}, \theta=10^{\circ}$ であるから

$$
T_{2}=21.3 \mathrm{~T}
$$

台付索を $62 \mathrm{~mm}$ (37 本線 6 撚) としたので 破断荷重 $=220 \mathrm{~T}$

従つて 安全率=10.3 となる。

\section{5. 制 動 装 置}

(1) 目 的

i）移動中の船体ブロックの回転ならびに船首尾方向の運動の調節

横移動漈しては重心位置を 1 本の wire で牽引するため, 計算上の重心と抗力中心の船首尾方向の位置が一致 しない場合が考党られる。たと党ばいま第10図において $\mathrm{G}$ を計画の抗力中心， $\mathrm{G}^{\prime}$ を実際の抗力中心であるとし， 重心位置に $\overline{G G}^{\prime}$ のずれが女るとするとき,船尾ブロックには実際の重心位置 $\mathrm{G}^{\prime}$ のまわりに図中の矢印の方向に

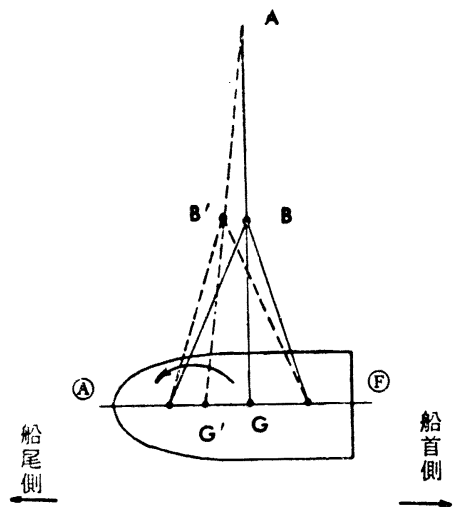

第 10 図 回転の moment が生じ，率引するに従つて牽引方向は $\mathrm{AB}^{\prime} \mathrm{G}^{\prime}$ 方向に 向から。また率引索取付用滑車 B は $\mathrm{B}^{\prime}$ 飞移り，船体は $\mathrm{G}^{\prime} \mathrm{A}$ 方向に 移動する汇したがつて次第に船首方向にずれて行く。な技実際の牽引 に当つては，最初の引張方向は滑車Bのずれによりかならずしも計画 抗力中心方向AGに向からものとはかぎらない。たと充壮第11 図 (B) に打いて $A \mathrm{~F}$ 方向に向つたとして子滑車 $\mathrm{B}$ は $(\mathrm{A})$ 図同様に $\mathrm{AG}^{\prime}$ 線上 汇位置するよう回転して，その後の船首尾方向のずれは(A)図と同 栐となる。

本制動装置は船体ブロック率引時の抗力中心を変える事を目的とし たもので，この装置の作動によつて牽引時船体ブロックの回転ならび 䚾船首尾方向のずれを容易汇調節する事が出来る。

ii）微動調節時の clamp

微動調節のようなかすかな, しかも緩漫な運動に対しては，船体は 


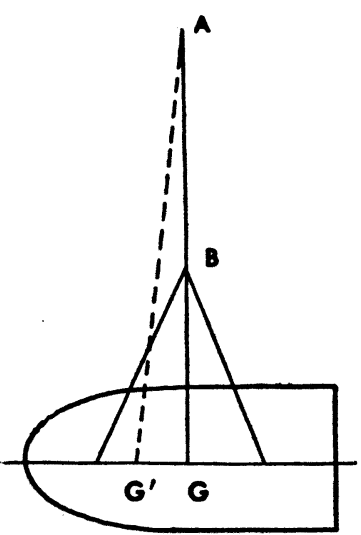

(A)

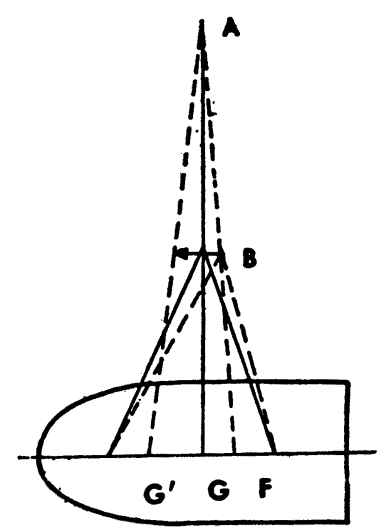

(B)

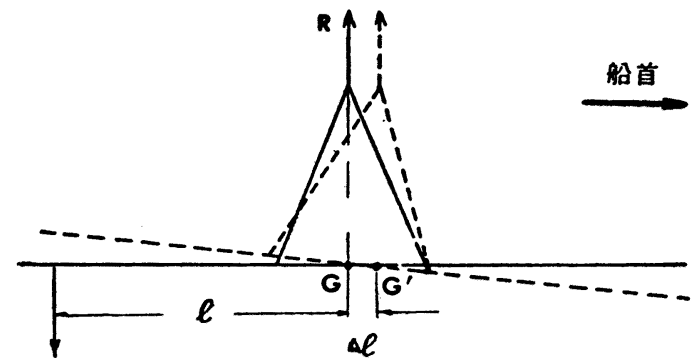

第 12 因

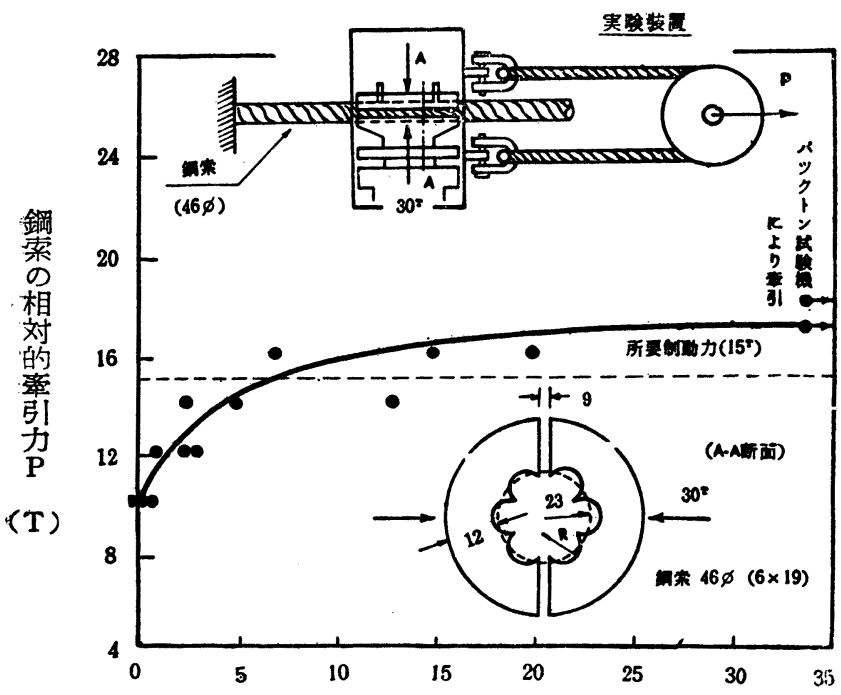

SLIP とよる鋼索移動量 (10 秒間) ( $\mathrm{mm}$ )

第 13 図 $30 \mathrm{~T}$ 水圧機による clamp の制動能力測定試駼結果
粘性の大なる液体の上に浮んでいる状態と なり慣性により相当移動する。従つて所定 の微動調節量を得るためには，この制動装 置による clamp によつて慣性を抑制する 必要がある。

(2) 配置

上述の理由による横移動中船体ブロック の回転, 船首尾方向運動の調節,ならびに横 移動後船体位置の微動調節に用いる clamp 用として, 船尾ブロックの船首尾の keel下 面に $30 \mathrm{~T}$ の水圧機を各 1 ケずつ取付计, これを通して $46 \mathrm{~mm} \phi$ の鋼索を第 9 図に示 すごとく移動方向に張り，この鋼索を clampすることにより船首あるいは船尾の 制動を行つた。

（3）所要制動力の算定

㖕画上の重心Gに対し，実際の摩㡜の合 力の中心 (抗力中心) $\mathrm{G}^{\prime}$ が船首または船尾 にあるとすれ代。第 12 図に执いて

$$
w(l+\Delta l)=R \cdot \Delta l
$$

ただし

$$
\begin{aligned}
& R: \text { 横移動率引力 } \\
& w: \text { 制動力 } \\
& l: \text { 計画上の重心 } \mathrm{G} \text { より制動力起点ま } \\
& \quad \text { での距離 }
\end{aligned}
$$

$\Delta l$ : 計画上の重心と抗力中心との位置 の差

いま重心 $\mathrm{G}$ と抗力中心 $\mathrm{G}^{\prime}$ の位置の算定 に $2 \mathrm{~m}$ の差があるものと想定して計算すれ ば,

i）抗力中心の方が計画上の重心より船 首にある場合

$\Delta l=2 \mathrm{M} 000, l=23 \mathrm{M} 000, R=84 \mathrm{~T}$ とすると船尾の制動力 $w$ は $w=6 \mathrm{~T} 720$

ii）抗力中心の方が計算上の重心上り船 尾にある場合

$\Delta l=2 \mathrm{M} \mathrm{000}, l=20 \mathrm{M} 360, R=84 \mathrm{~T}$ とすると船首の制動力 $w$ は $w=7$ T 53

従つて重心と抗力中心との算定に $2 \mathrm{~m}$ の 差がある場合にはこれらを一致せしめるた めの所要制動力の静荷重は $8 \mathrm{~T}$ 弱となる。

しかし実際には船体の移動中固定台 ribband と滑走台の接触等による抵抗增加 が考えられるので，安全率を倍加し所要制動力を約 $15 \mathrm{~T}$ として考えた。

（4） $15 \mathrm{~T}$ の制動力を得るに必要な水圧機の能力

著者は過去に执いて得られた経験ならびに二, 三の予菊英験の絬果から $15 \mathrm{~T}$ の制動力を得るには $30 \mathrm{~T}$ の水圧 機が適当であると考劣，下記の実験においてこれを確認した。第 13 困は鋼索の clamp 実験用装置ならびに実験 
沉よる $30 \mathrm{~T}$ 水圧機の制動能力を示す。

これとよると slip とよる鋼索の移動量は鋼索の率引力が $10 \mathrm{~T}$ まで 0 であるが, $10 \mathrm{~T}$ から $15 \mathrm{~T}$ までは徐 々に增加する。この場合この籁囲内では $30 \mathrm{~T}$ 水圧機による制動が有効範囲にあるが，16 T を超えると急激に 增大し clamp の能力が無くなることを示している。

な㧍制動用鋼索として 46 (6×19 共芯) のものを使用したが，この場合破断荷重は $132 \mathrm{~T}$ であるから上記の ごとく制動力を $15 \mathrm{~T}$ とすれば,

安全率は $132 \mathrm{~T} \div 15 \mathrm{~T}=8.8$ となる。

\section{6. 押 出 装}

押出装置は横移動固定台 8 条の各々に $50 \mathrm{~T}$ journal jack を備え指揮所よりの号令により一斎に作動し，船体 が滑走を始め船体の移動速度が jack の押出速度より早くなり, jack の尖端が滑走台を離れるまで突出を続ける こととした。押出装置概略は第 14 図のとおりである。

以上の計画により牽引装置を決定したが，実際の横移動沈いては最大率引力 $81 \mathrm{~T}(\mu=0.029)$ が記録されて いるので初期の計画は妥当であつたものと考劣られる。また横移動抗力中心の算定は計画重心位置より $5200 \mathrm{~mm}$ の範囲にあり, 制動装置は抗力中心の移動 $2 \mathrm{~m}$ までを考兄て計画したが, これは充分安全側にあるから, 従つて 牽引索を1本として計画したことは種々の設備を単純化し，かつ winch を連続運転することができたため移動 時間の短縮に大いに有効であつたものと思われる。

な拈押出装置は本章 $\$ 1$ の 3 の項で 述べたごとく実際には使用する必要が なかつた。

\section{\$6 縱移動動引装置}

縦移動率引の方式は winch による 控降し方法を採用し, 主牽引索は1 本 とし 5 枚滑車により增加した。 winch 壮縦移動に打いて子撩揚げ可能である よう $40 \mathrm{~T}$ winch とした。

ただし移動開始時における抧揚時の 大巾な摩擦抵抗の上年に対しては, 後 述するごとく押出 jack を併用するも のとした。

樅移動装置に用いた索具類のらち, winch 拈よび滑車は港揚時の最大摩擦 係数が 0.03 であるとして計画し, 鋼 索は撩降時の最小摩擦係数が 0.01 で あるとして約 9 乃至 10 の安全率を取 るよう計画した。

本装置の概要ならびに索具決定の算 式は次のそおりである。

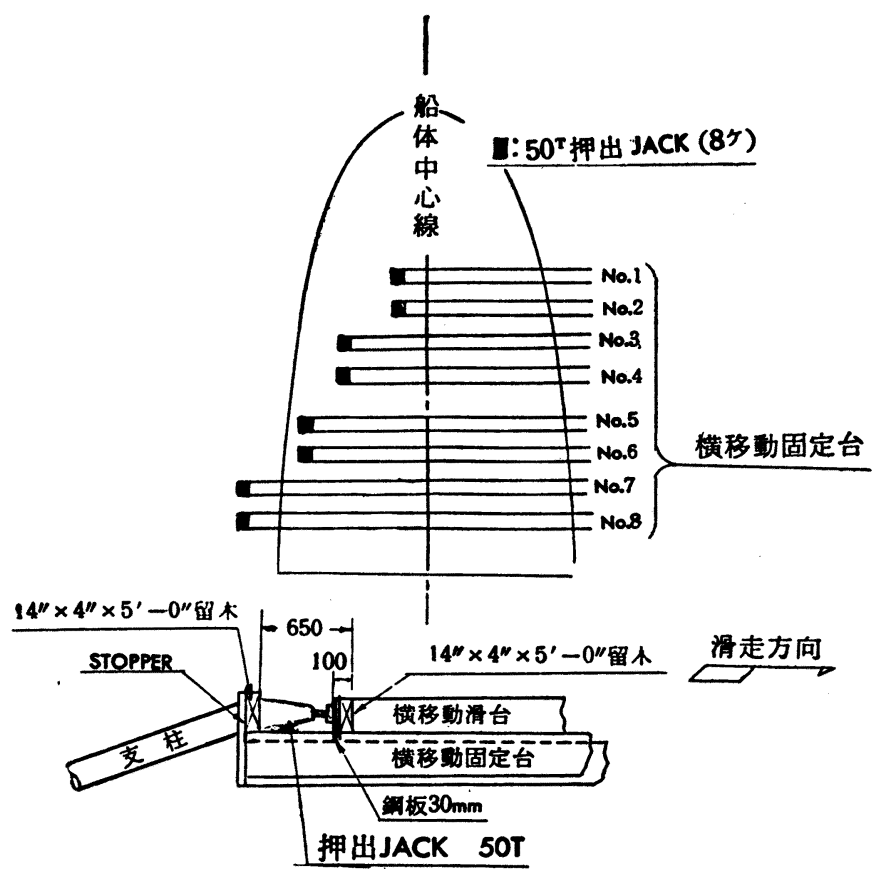

第 14 図横移動用押出 jack の配置ならびにその取付要檚

\section{1. 所要率引力}

いま $R$ : 所要索引力 $\theta$ : 移動後の傾斜角度 $W$ : 総移動重量 $\mu$ : 獣脂の摩擦係数 とすれば, 所要率引力 $F$ は

$$
R=W \cos \theta(\tan \theta-\mu)
$$

$W=2,800 \mathrm{~T}, \quad \theta=\frac{56}{1000}$ (縦移動台最大勾配)

爸揚時の所要率引力（ただし $\mu=0.03 ）=157 \mathrm{~T}+84 \mathrm{~T}=241 \mathrm{~T}$

撩降時の所要引力 (沈だし $\mu=0.01)=157 \mathrm{~T}-28 \mathrm{~T}=129 \mathrm{~T}$ 


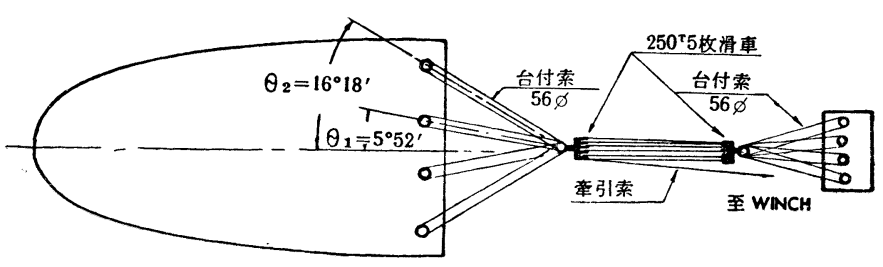

第 15 図綐移動用率引装固配置要領

\section{2. 滑車}

滑車は㨢掦可能なよ (test load:350T) 5 枚滑車とした。

\section{3. 率引索}

5 枚滑車を第 15 図のように使用 したとき率引索の最大㼘力を求める と.

$$
T_{1}=\frac{X^{n}(X-1)}{X^{n+1}-1} R \text { である。 }
$$

ただし $T_{1}$ : 率引索の最大緊力

$X: 1+($ 各滑事に新汗る loss)

$n$ : 滑車の数

$R$ : 縦移動所要率引力

(1) 挍揚の場合

$R=241 \mathrm{~T} \quad n=10$ であり $X=1.06$ とすれば， $T_{1}=28.8 \mathrm{~T}$

(2) 撩降の場合

$R=1.29 \mathrm{~T} \quad n=10$ であり $X=1.06$ とすれば， $T_{1}=15.35 \mathrm{~T}$

率引索を $46 \mathrm{~mm} \phi(29$ 本線 6 撚 filler 入り)としたので, 破断荷重 $132 \mathrm{~T}$

従つて, 港揚時の安全率 $=4.58$

港降時の安全率 $=8.6$ となる。

\section{4. 台 付 索}

1 本の台付索を第 15 図に示すごとく endless に 8 本政けとすれ!゙，台付索にかかる荷重は

$$
T_{2}=\frac{R}{4\left(\cos \theta_{1}+\cos \theta_{2}\right)} \text { で示される。 }
$$

ただし $T_{2}=$ 台付索 1 本にかかる荷重

$$
\begin{aligned}
\theta_{1}, \theta_{2} & =\text { 台付索の角度 } \\
R & =\text { 縦移動所要索引力 }
\end{aligned}
$$

（1）港揚の場合

$$
R=241 \mathrm{~T} \quad \theta_{1}=5^{\circ} 52^{\prime} \quad \theta_{2}=16^{\circ} 18^{\prime} \text { より } \quad T_{2}=30.8 \mathrm{~T}
$$

(2) 撩降の場合

$$
R=129 \mathrm{~T} \quad \theta_{1}=5^{\circ} 52^{\prime} \quad \theta_{2}=16^{\circ} 18^{\prime} \text { より } \quad T_{2}=16.5 \mathrm{~T}
$$

台付索を $56 \mathrm{~mm}$ (37 本線 6 然) としたので破断荷重 $=174 \mathrm{~T}$

従つて，挖揚時の安全率 $=5.65$

挖降時の安全率 $=10.54$ となる。

\section{5. winch}

winch は移動のため特に製作することとし，これを第 7 船台船首に設咀し，横移動，縱移動ともにこのwinch で率引を行うものとした。獣脂の摩擦係数を 0.03 とすれば, 横移動, 縱移動を綜合してwinch の最大の荷重 は，28.8T でむるが，摩擦係数等の増加を見込んで $40 \mathrm{~T}$ winch とした。そして，その㨢取速度を每分 $5 \mathrm{M}$ と し，船体移動速度を每分 $500 \mathrm{~mm}$ とした。この船体移動速度は縦移動中急停止時の衝繋力および移動中滑走台が 固定台の ribband に与方衞撃力等を考虑して決定したものである。

\section{6. 押 出装置}

縦移動にて挍降しを始める前，行止支柱の取外しおよび滑走面の密着を取外す目的で船体を約 $25 \mathrm{~mm}$ 捲揚げ ることとした。この抶掦げは縱移動率引索により行うのであるが, 補助装置として縱移動滑走台の船尾端に50T journal jack を片舷2ケずつ装置するものとした。

なおこの押出装置は䄪 $25 \mathrm{~mm}$ 撩揚げ後は行止支柱と同時に取外すものである。

以上の計算により縱移動率引装置を計画したが，実際の縦移動にないては撩掦は約 $35 \mathrm{~mm}$ 行つた。ただしそ 
の際には押出 jack を併用しており所定の最大 挛引力は記録されなかつた。また最小摩擦係数 が 0.0071 乃至 0.0099 であり, 抒拈む初初期の 計画どおりであつた。船体移動速度は栱移動時 の ribband の一部破壞等より考㝋てあまり高速 付するとは出来ないので，毎分 $500 \mathrm{~mm}$ 位が 適当であつたものと考觉られる。

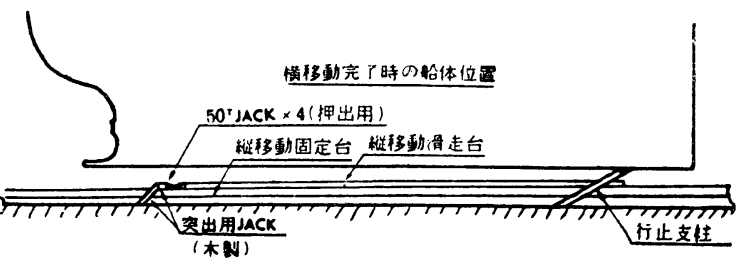

第 16 図縱移動用押出装置の配置位置

\section{$\$ 7$ 移 動 台 構 造}

移動台權造はすべて川㥓重工業株式会社の進水台構造にならい施工することとした。本移動工事で特に考虑を 法つた点について列挙すれば次のと抢りである。

1. 横移動台の滑走面は水平面とし，その高さおよび滑走台の長さを 2 条ずつ等しくした。

2. 横移動固定台は縱移動滑走台の上方を横切るようにした。

3. 横移動滑走台と固定台 ribband の間隙を $75 \mathrm{~mm}$ とした。(ただし縱移動台の場合，上記間隌は $11 / 8$ 时）

4. 第 7 船台の横移動固定台㧍よび滑走台は横移動完了後も取外さず絽移動時の poppet として使用した。

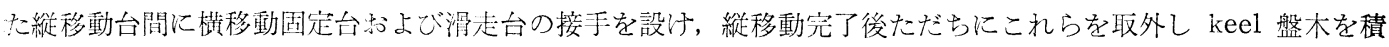
さことが出来るようにした。

5. 船尾ブロックの建造就よび横移動のための基礎は水平であるため, 船体または移動台の高さ汇応じて keel 艋木用，槿移動台用の concrete 盤木を置くこととした。

concrete 盤木は次の要領で計画した。

i） 横移動固定台据付工事の期間を短くし，移動時の固定台の沈下を少くするとともに各条の固定台の沈下を 均等にするため，固定台下面と concrete 盤木の間隔を出来るかぎり小さくし，かつ各条の固定台下の盤木（木 製）の高さをほぼ等しくした。

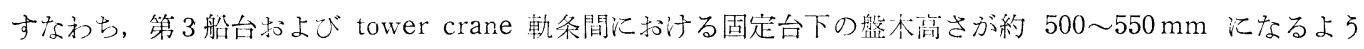

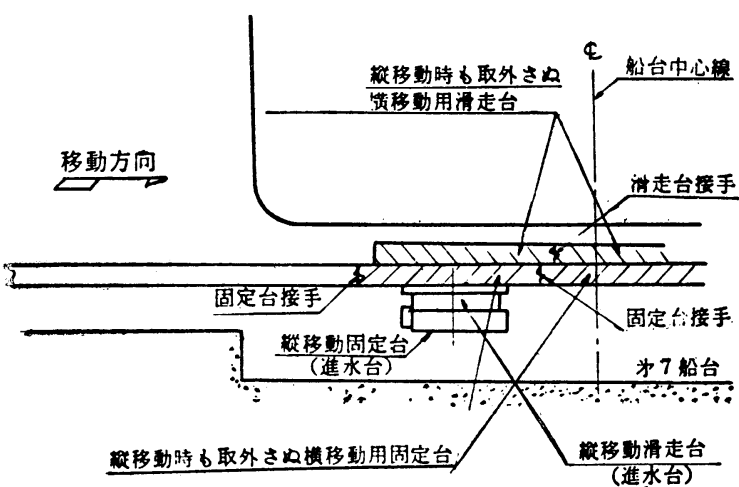

第 17 図縦移動 poppet 亿使用する横移動台 concrete 盤示を配羁した。

ただし第 7 船台上は半永久的に設置するた め, 第 7 船台建造船の進水老考慮し進水台（縱 移動台）の滑走面より低くした。

ii）第 7 船台の進水台（縦移動台）の外側は 船台が強固でないため, 各横移動台下に concrete 盤水を置き右舷側はその巾を增し受圧面 積を大きくした。

すなわち第 7 船台上右舷側 concrete 盤木の 巾を3M500 として，その他は1M930 とした。

移動工事の結果，前述のごとく No. 3，No. 4 およびNo. 5, No. 6 の横移動台の獣脂が嬖開し たが，これは滑走台上の船体の支え力が不均一で，これらの滑走台に圧力が均等化分布せず滑走台汹端の圧力が 増加したためであると思われ る。

また縦移動台の獣脂の内側が 一部䢃開したが，これは船尾の 縦移動 poppet の構造が両䑨に またがる上置 (木材) の上に締 め矢および上駒学置く構造であ つたため, 上蹎が彎曲して内側 刃压力が增したためと考光られ

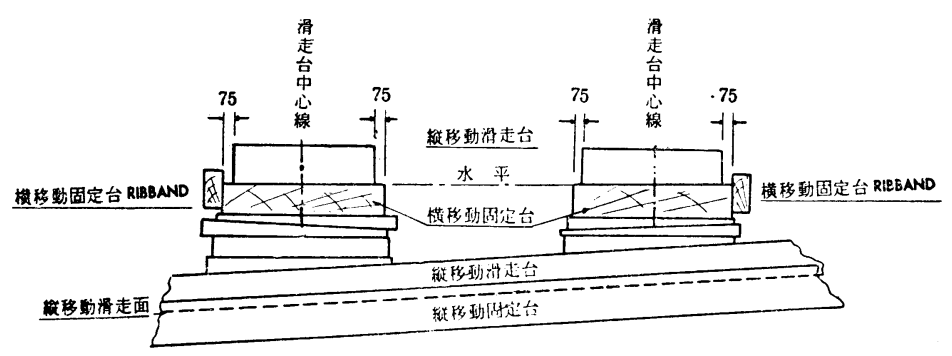

第 18 図横移動台々縱移動台の関係 


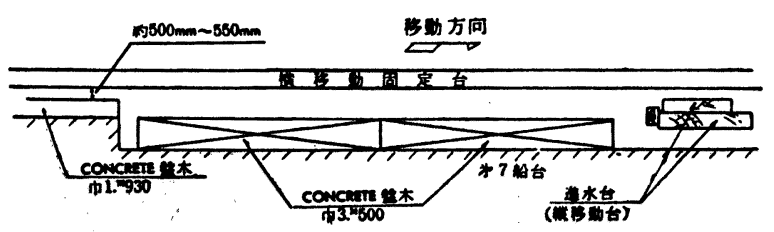

第 19 図 concrete 盤木
る。

横移動時の船体の船首尾方向の旗動沛よび回 転運動については, このため No.7 の横移動滑 走台が固定台の ribband に当り一部 ribband に 亀裂を生じた。したがつて横移動固定台の ribband および横支柱には考虑を払う必要があ ると思われる。

\section{$\S 8$ setting 作 業}

setting 作業は横移動㧍よび縱移動共川崎重工業株式会社の進水における setting 作業に準じて施工すること とした。

横移動終了後綎移動に対する setting 作業が始つた時緃移動牽引索装置前に若干の縱移動滑走力が生じること となる。この縦移動滑走力を防止するため横移動完了点に行止支柱を船体に取付けた。

行止支柱は $120 \mathrm{~T}$ の静荷重のほかに setting 工事による衝撃を考兄, この衝撃値を $120 \mathrm{~T}$ とて, $240 \mathrm{~T}$ の 設計荷重で計画した。行止支柱の起倒は第 20 図に示すごとく $8 \mathrm{~T}$ 水圧機を取付けこれにより操作した。

行止支柱は横移動完了点のみならず,・縦移動完了点にも取付け縦移動固定台船尾の stopper とともに縦移動完: 了後の滑走力を止めるようにした。

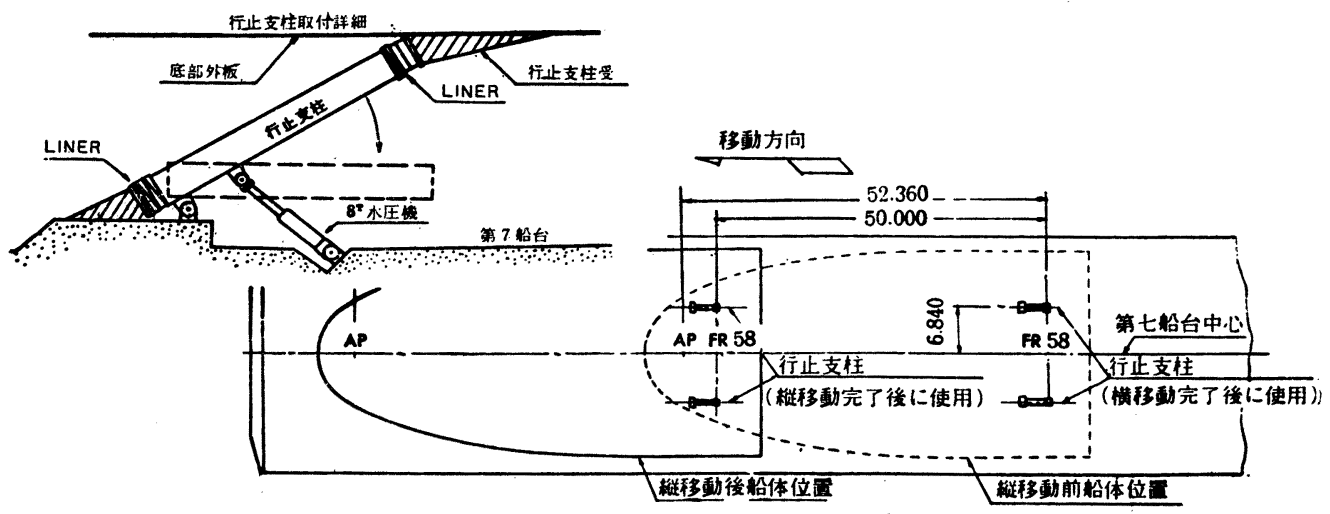

第 20 図行止支柱配置要領

\section{$\S 9$ 横移動啳の船体位罣調節}

横移動時に括いて船体が停止した後，船体中心線を第 7 船台中心線に合わせる調節作業，すなわち船体中心線 の位置の調節作業が必要である。従つて横移動固定台に stopper および jack を設置し, stopper により船体を 所定の位置に停止させたのち jack により微動調節を行つた。

横移動 stopper 括よび jack は第21図に示すよ 5 Ko. 4 および No.7 の横移動固定台に stopperをまた No. 3 および No.8 の横移動固定台に 3 台ずつ 50 T journal jack を配置した。

調節作業はまず所定の停止位置の約 $500 \mathrm{~mm}$ 手前で一たん船体を停止させ stopper に取付けた木製 liner 調節する。この時船体が所定位置より $20 \mathrm{~mm}$ 行過ぎた位置で停止するよう liner を調節しておき, $50 \mathrm{~T}$ journal jack により微動調節を行い船体中心線位置を調節した。

なお stopper および jack 受の構造は第 21 図に示すとおりである。

以上の計画で実施した結果は最終の停止位置 (jack 操作前の位置) は, 当初の計画で戊舷に $20 \mathrm{~mm}$ 行過ぎ たところで停止させる予定であつたにもかかわらず，右舷に寄つた位置（船首計测位置て $85 \mathrm{~mm}$, 船尾計測位置 で $94 \mathrm{~mm}$ 右舷寄りの位置) であつた。したがつて jack の操作では船体中心線と第 7 船台中心線を一致させる ことが出来なかつたため船首計測位置で $87 \mathrm{~mm}$, 船尾計測位置で $82 \mathrm{~mm}$ 右舷に寄つた位置で船体中心線を第 7. 船台中心線にほぼ平行に調節した。

また jack 操作中, その部分の固定台が持上り第 21 図の図中に示す $11^{1 / 2} \phi$ 締付 bolt が曲つた。 


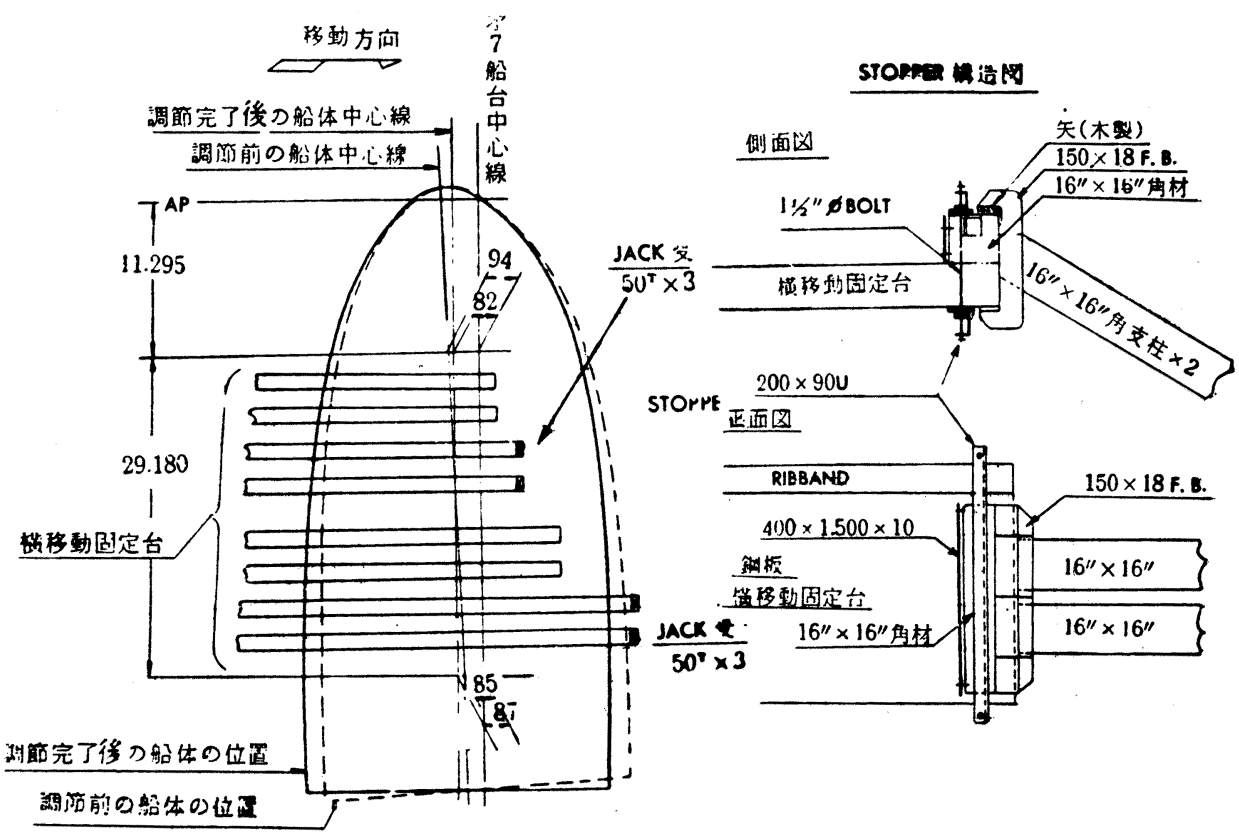

したがつて

第 21 図 横移動用 stopper 配置要領

1. 横移動後の船体位置調節は jack で行うことは容易であつた。

2. 船体を $20 \mathrm{~mm}$ 行過ぎた位置で停止させるよう計画したが, $200 〜 300 \mathrm{~mm}$ 行過ぎた位置で停止させた方が よいと思われる。

3. jack 受の構造はも5少し強い構造とし,この部 分の固定台を第 22 図の如く船台から anchor bolt で 固着する必要があると思われる。

4. 調節用 jack は横移動固定台の長さの関係上No. 1 固定台（最船尾固定台）に取付けることが出来なか つたが，これは No.1 固定台に取付ける方が有効であ ると考えられる。

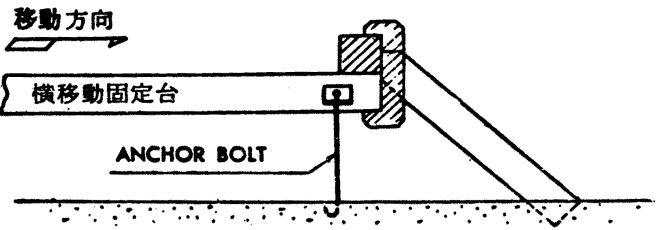

第 22 図 anchor bolt 取付要領

\section{\$10 兆移動後の船体位置調節}

縦移動において船体が停止した後, 船体を正規の位置, 勾配に据付ける調節作業が必要である。 すなわち

a）船首尾方向の位置の調節。

b) 船体中心線の位置の調節。

c） keel 勾配拉よび左右舷の傾きの調節。

このうち船首尾方向の位置の調節と船体中心線の位置の調節は獣脂面への載荷時間が長くなれば摩擦が増加す るため縦移動停止直後に行うこととしたが，keel 勾配および左右舷の傾きの調節は縦移動 poppetを取外した後 でなければ行えないので移動 4 日後に行つた。

\section{1. 船首尾方向の位置の調節}

縦移動完了点の固定台両舷に stopper を設け，これに片舷4ケずつ 50 T journal jack を設けた。

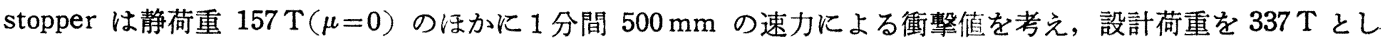

て計画した。stopper の構造は第 23 図に示すと扣りである。

この調節作業は横移動の場合と同様に，まず所定の停止位置より約 $500 \mathrm{~mm}$ 手前で一たん停止させて stopper の木製 liner を調節し，微動調節は stopper に設けた jack で行つた。 

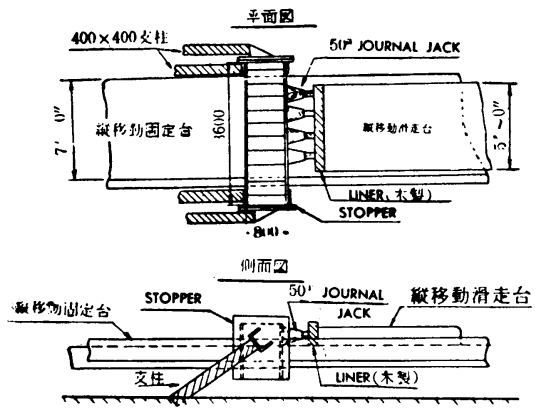

移動方向

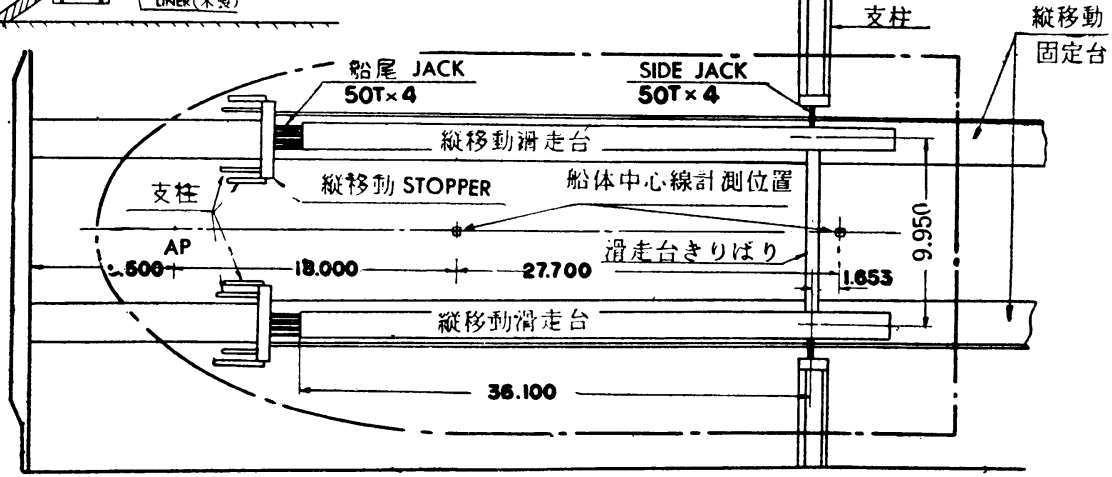

第 23 図縦移動後の船体中心線位置調節装㟨娶領

実祭の移動工事では船体が所定位直で停止したため，この調節作業を行う必要はなかつた。

\section{2. 船体中心線の位置の調節}

前述の縦移動 stopper に取付忛た片舷 4 ケずつの 50 T journal jack (船尾 jack)，および縱移動光了点の滑走 台の船首附近に横方向に取付けた jack (side jack) でこの調節作業を行つた。

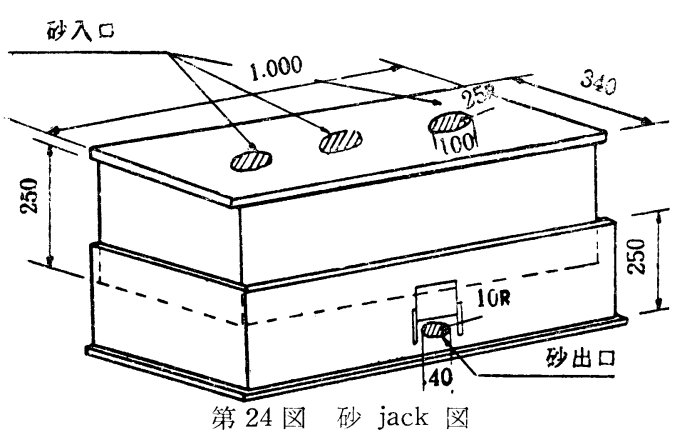

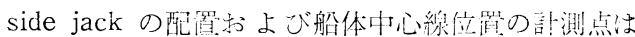
第 23 図に示すと拉りである。

\section{3. keel 勾配および左右舷の傾きの調節}

この作業には第 23 図に示す砂 jack 学使用すること とし, keel の下にはkeel 本船木( (中心間隔 $1 \mathrm{M} 200$ ) の閒に 37 丁の砂 jackを拆人した砂盤木を配留し， 両舷には片舷 3 組の腹本盤木の他に片舷 5 組の腹砂盤 木を配置した。

ただし keel 本盤木，腹本盤木はこの調節作業時に は低くして执き，調節作業完了後逐次締的て行つた。

砂 jack は $20 \mathrm{~mm}$ 鋼板製とし射压力 $200 \mathrm{~T}$, 个降速度を 1 分間 $5 \mathrm{~mm}$ ，最大下り代穵 $140 \mathrm{~mm}$ とて計画した

\section{第 3 章 結}

$\overline{\overline{\bar{n}}}$

本方式の主旨にもとついて以上に选べたごとく移動工事に対する諸種の計画が行われ，これが実施の第 1 船は 大体計画当初の工期内にて完成したのであるが，工事上の諸準備ならびに第 1 船であるがための工事上の余裕を 得るがため，かならずしも本文の主旨ならびに工程説明の項沈いて述べたとおりにはならなかつた。しかし第 2 船以降の工程は添とえど 100\%計画值に近い順調な進捗状況を示し，本計画の妥当州をを物語つている。そこで 以上によつて本方式の主旨ならびに移動工事の計画および絬果を綜合して次の事が云い得ると考えられる。

\section{1. 主旨ならびにエ程に関して}

1.1 本万式により予め組立定盤に打いて建造される組立ブロックは，従来より行われている地上組立ブロッ

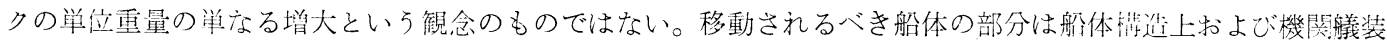

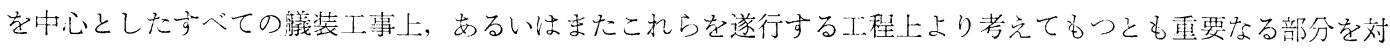


象とせ枕ばならね。

1.2 船台に㧍ける建遥期間は船台の回㖕率ひいては生産量を決定するものである。従つてこの船台期間は船 台, 地上組立定艋打よび crane 等の能力により決定されることは㓜論であるが，もつとも重要なことはこの船 台期間中に艤装工事を終了せしぬ得るよう設備および人員の稼働能力等その他すべての要素を綜合的に検討の上 決定さるべきである。

1.3 本万式汇よる建造が引続き連続的に行われるときは, 移動されるべき船体の建造日数と移動後の船体の 建造日数と移動後の䇝装日数が各々等しいことが望ましい。

\section{2. 移動工事に関して}

2.1 縦移動の場合は進水台を利用すれば通常の進水工事と変らずほとんど問題はないが，横移動の場合は各 軌条 (各移動台) にかかる圧力を均等にすることが工作的に困難な点がある。従つて横移動の場合は出来るだけ 䩔条数を少くするうがよい。

2.2 移動工南の場合は船体の沈下は避けることは出来ないから, 計画位监より予め船体を高く据付けること が必要で女る。本移動工事のごとき移動重量, 移動距離および移動台構造の場合は計画位置より $120 \mathrm{~mm}$ 高く据 付故ればよい。

\section{3. 獣脂の摩擦係数ならびにその特性に関して}

3.1 移動に使用した獣脂に一部䢃開, 亀裂等の現象が起きたが，これらは第 1 回移動工事の経験により，一 部の計画変更により防止出米た。従つて獣脂面化対して夏季, 冬季を問わず日光の直射を避け, また単冬季に寒 気にさらすことを踇ければ，このような移動工事に獣脂を使用することは可能である。

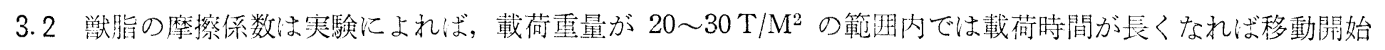
時の摩擦係数は 20〜 30 mm 移動後の摩擦係数にくらべて非常に高く，たとえば載荷時間 4 時間の場合には，前

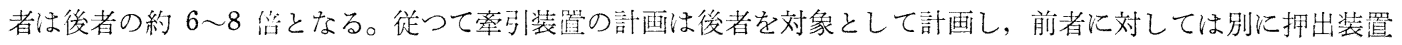
を設汁て移動開始時の率引力を援助する方法をとるのがよい。

\section{4. 率引カならびに抗カ中心に関して}

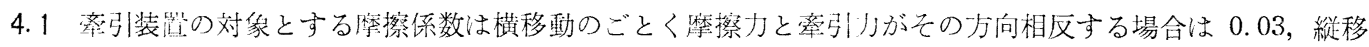
動の港降しのごとくその向が一致する場合は 0.01 として計画すれば充分である。

4.2 横移動は 1 本の wire で重心点を率引する方法をとつたが，この方法では船体の回転運動少よで船首尾 方向の運動は避けることは出来ないが，これに刘しては ribband および横支柱を強固にすればこの方法でも差 支えない。

4.3 率引の速度は每分 $500 \mathrm{~mm}$ としたが，移動中の諸種の状沉判断のために打括む放適当であつたと考えら

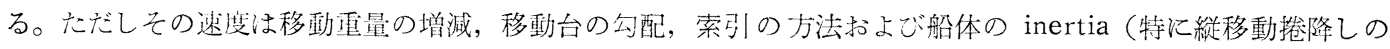
際の停止侍）等を考意して調節されるべきものである。

4.4 横移動に用いた水压機式制動装置はブロックの回転運動および船首尾方向のずれを調整する上にきわめ て有効であつた。

また微動調節に際して船体ブロックを固定するのにも有効で岀つた。

\section{5. 計測に関して}

5.1 移動工事垁施に対して種々の計测を行つたが，3,000T に近い巨大な船体ブロックをきわめて正確な位 置を保ちつつ, かつ時間的にもきわめて正確に滑走移動せしめるためには移動中必要な事象の变化が刻々表示さ れることが必要である。

5.2 移動中の牵引力は移動の状態を綜合的に表示するものと考兄られ，第 1 船の移動に際しては二重あるい は三重の方法です全を期して行われた。しかし結果的にみて充分注意深く準備された歪計による計測方法のみで 充分である。

\section{後記}

本建造方法を行うに際し，このう法の中核をなすところの移動作業の計画ならびに実施については東京大学工 一学部吉識，木原雨教授，大阪大学工学部原田，寺沢兩教授より懇切なる御指導を賜つた。

また移動作業当日に行つた諸計测に対しては運輸技術研究所溶接部の皆様から数々の御助力を頂いた。なお摩 擦係数測定実娩に当り新三菱重工業株式会社神戸造船所より ball 式進水台および附属品一式を拝借した。ここ こ併記し，もつて謝意の一端を表する次第である。 